\title{
El evemerismo como motivo retórico en la literatura apologética cristiana
}

\author{
Ana Alonso Venero \\ Universidad de Cantabria \\ alonsoveneroana@gmail.com
}

Los dioses de la mitología greco-romana constituyen un tema central en la invectiva de los apologistas contra el paganismo ${ }^{1}$. Para ellos, los dioses son sólo seres humanos, divinizados después de su muerte. El discurso cristiano incide en los relatos que describen el nacimiento, la muerte e incluso el lugar de enterramiento de los personajes mitológicos para demostrar su existencia humana. El argumento no es exclusivo del cristianismo y había sido tratado por algunos intelectuales griegos ${ }^{2}$, en especial por Evémero de Mesene ${ }^{3}$. Su obra, la Historia Sagrada, escrita alrededor de los años 272-271 a.C., se ha perdido. Según el testimonio de Eusebio de Cesarea ${ }^{4}$, Evémero descubre en la isla legendaria de Panchaia un templo dedicado a Zeus Triphylius. En su interior encuentra una estela de oro en la que aparecen descritas las hazañas más importantes de los reyes del país: Urano, Cronos y Zeus; es decir, hombres que gobernaron y sirvieron a la humanidad y que fueron deificados después en agradecimiento.

\footnotetext{
${ }^{1}$ Para una introducción a la literatura apologética, vid. R.M. Grant, Greek Apologists of the Second Century, London, 1988; J.-C. Fredouille, «L'apologétique chrétienne antique: naissance d'un genre littéraire», REAug 38 (1992) pp. 219-234; Idem, «L'apologétique chrétienne antique: metamorphoses d'un genre polymorphe», REAug 41 (1995) pp. 201-216; B. Pouderon y J. Doré (eds.), Les Apologistes Chrétiens et la Culture grecque, Paris, 1998; M. Edwards, M. Goodman y S. Price (eds.), Apologetics in the Roman Empire. Pagan, Jews and Christians, OxfordNew York, 1999; M. Fiedrowicz, Apologie im frühen Christentum. Die Kontroverse um den christlichen Wahrheitsanspruch in den ersten Jahrhunderten, Paderborn, 2000; Av. Cameron, «Apologetics in the Roman Empire - A genre of intolerance?», J.-M. Carrié y R. Lizzi Testa (eds.), «Humana Sapit». Études d'antiquité tardive offertes à Lellia Cracco Ruggini, Turnhout, 2002, 219-227; A. Wlosok y F. Paschoud (eds.), L'Apologétique chrétienne gréco-latine à l'époque préniceniénne. Entretiens sur l'Antiquité Classique 51, Vandoeuvres-Genève, 2005; B. Pouderon, Les apologistes grecs du II siècle, Paris, 2005; M. Kahlos, Debate and Dialogue. Christian and Pagan Cultures c. 360-430, Hampshire, 2007; J. Ulrich, A.-C. Jacobsen y M. Kahlos (eds.), Continuity and Discontinuity in Early Christian Apologetics, Frankfurt, 2009, 79-95; A.-C. Jacobsen, J. Ulrich y D. Brakke (eds.), Critique and Apologetics. Jews, Christians and Pagans in Antiquity, Frankfurt, 2009.

${ }^{2}$ Así el sofista Pródico de Ceos (ca. 460-399 a.C.), contemporáneo de Sócrates y discípulo de Protágoras (Cic. De nat. deor. 1, 42, 118; Eur. Bacch. 272-286), y el estoico Perseo de Citio (ca. 307-243 a.C.), discípulo de Zenón y contemporáneo de Evémero (Cic. De nat. deor. 1, 15, 38).

${ }^{3}$ También conocido como Evémero de Agrigento (ca. 300 a.C.). Sobre la figura, la obra y el pensamiento de Evémero, vid. S. Spyridakis, «Zeus is Dead: Euhemerus and Crete», CJ 63, 8 (1968), pp. 337-340; V. Domínguez García, Los dioses de la ruta del incienso: un estudio sobre Evémero de Messene, Oviedo, 1994; M. Winiarczyk, The Sacred History of Euhemerus of Messene, Berlín y Boston, 2013 (reimpr. ingl. 2002).

${ }^{4}$ Eus. P.E. 2, 2, 52-62. Pueden verse otros testimonios sobre Evémero en: Plu. De Is. et Os. 23; Cic. De nat. deor. 1, 42, 119; Diod. Sic. 5, 41-46 y algunos fragmentos del libro sexto (en Eus. P.E. 2, 2, 52-62).
} 
La interpretación de Evémero acerca de los dioses presenta un marcado carácter físico, enfatizando los rasgos humanos que describen los relatos mitológicos sobre tales divinidades y su condición mortal. Se trata, por tanto, de una exégesis histórica y racionalista, de manera que los dioses del paganismo quedan reducidos a la condición de seres mortales, divinizados después de su muerte. Las razones que han llevado a los hombres a efectuar su divinización pueden relacionarse con el reconocimiento, la admiración o el temor que esos personajes provocaron entre sus contemporáneos. Según esta interpretación, la tradición mitológica únicamente relata las aventuras -humanas-, de los mortales, engrandeciendo o adornando algunos de sus actos. Las teorías de Evémero se difunden especialmente entre las ciudades del entorno helenístico y, a partir de ahí, llegan a Roma, probablemente introducidas por el poeta Ennio ${ }^{5}$. La reacción de los intelectuales paganos a estos planteamientos generalmente es de hostilidad, y califican a Evémero de ateo e impió ${ }^{6}$.

\section{EL ORIGEN HUMANO DE LOS DIOSES}

Los apologistas encuentran en la interpretación evemerística de los mitos paganos los argumentos para fundamentar sus teorías acerca del origen no divino de los dioses y su ataque contra el paganismo ${ }^{7}$. Sin embargo, existe una actitud ambigua con respecto a la figura de Evémero. Para los cristianos, Evémero es un sabio que denuncia a los falsos dioses, pero también es un impío, puesto que con sus teorías desacraliza la concepción que se tiene sobre lo divino. Por ello no sorprende que un mismo autor recurra a los planteamientos evemerísticos para formular su ataque contra los dioses del paganismo y al mismo tiempo denuncie la impiedad y el ateísmo de Evémero. Es posible que ésta sea la razón por la cual no todos los apologistas mencionan a Evémero de forma explícita, pese a que la mayor parte de ellos recurre a los argumentos de la interpretación evemerística. Así, por ejemplo, tanto Arístides como Justino expresan su rechazo hacia la caracterización humana de los dioses, describiendo sus sufrimientos, debilidades, y en definitiva, sus conductas propias de los hombres (Arist. Apol. 9; 1213; Just. 1 Apol. $21-25 ; 53-54)^{8}$. No obstante, no se encuentra en sus obras ninguna alu-

\footnotetext{
${ }^{5}$ De su obra Euhemerus (traducción al latín de los escritos de Evémero), sólo se conservan algunos fragmentos (Cic. De nat. deor. 1, 42, 119).

${ }^{6}$ Cic. De nat. deor. 1, 42, 119; Sext. Emp. Adv. Math. 9, 17. En tono irónico, Plutarco señala que, salvo Evémero, nadie más llegó a conocer la famosa isla (De Is. et Os. 23).

${ }^{7}$ Para una perspectiva general sobre la influencia del evemerismo en la literatura apologética cristiana, vid. R.P.C. Hanson, «The Christian Attitude to Pagan Religions up to the time of Constantine the Great», $A N R W$ II, 23, 2 (1980) pp. 157 y 172-183; C.A. Contreras, «Christians views on Paganism», ANRW II, 23, 2 (1980) pp. 978-979 y 986; J. Pépin, «Christianisme et Mythologie. L’Evhémerisme des auteurs Chrétiens», De la Philosophie Ancienne á la Théologie Patristique, London, 1986 (reimpr. 1981), pp. 1-16 ; J.-M. Vermander, «La polémique des Apologistes latins contre les Dieux du paganisme», RecAug 17 (1982), pp. 21-30; B. Pouderon, Athénagore. Supplique au sujet des Chrétiens et Sur la Résurrection des Morts, SC 379, Paris, 1992, pp. 328-330.

${ }^{8}$ Las citas de Arístides se harán según la ed. de B. Pouderon, M.-J. Pierre, B. Outtier y M. Guiorgadzé, Aristide. Apologie, SC 470, Paris, 2003, y las de Justino según la ed. de C. Munier, Justin. Apologie pour les
} 
sión específica a Evémero o a su doctrina. Ni siquiera aparece expresada en términos directos la equiparación entre los dioses y los hombres, a excepción de la referencia que hace Justino al culto de Antínoo (Just. 1 Apol. 29, 4) . Taciano tampoco menciona a Evémero, pero sí alude, en cambio, a los planteamientos de uno de sus discípulos, probablemente León de Pella (Tat. Orat. 27) ${ }^{10}$. Atenágoras es el primero que expone los fundamentos de la tesis de Evémero: «Mas los dioses de que gusta el vulgo y que dan su nombre a las estatuas han sido meros hombres, como puede averiguarse por las historias que de ellos tratan» (Athenag. Leg. 26, 1) ${ }^{11}$. Aunque Atenágoras no menciona a Evémero, sus planteamientos coinciden con las líneas principales de la argumentación de éste, señalando algunos de los ejemplos que aparecen en los relatos mitológicos acerca de aquellos hombres que han sido divinizados por su fuerza, su habilidad o su belleza, o bien por el temor y la admiración que despertaron (Heracles, Perseo, Asclepio, Antínoo, etc.) (Athenag. Leg. 29-30). La base de su discurso radica en el testimonio acerca de los dioses egipcios de Heródoto y de Apolodoro, o en la denominada Carta de Alejandro a su madre, atribuida a Alejandro Magno, aunque se supone que es obra de León de Pella ${ }^{12}$. Dado que la exposición de tales principios sugiere que Atenágoras conoce las doctrinas de Evémero, su omisión puede ser fruto de una decisión voluntaria, posiblemente relacionada con esa actitud ambigua, a la que antes aludíamos. El hecho de que las doctrinas de Evémero, consideradas impías, sean objeto de censura y reprobación no impide que puedan utilizarse para una mejor formulación del ataque al paganismo. La actitud de Teófilo de Antioquía con respecto a Evémero es muy semejante a la de Atenágoras. Aunque Teófilo es el primer escritor cristiano en mencionar su nombre, la alusión está formulada en términos despectivos: «Superfluo fuera citar las teorías del impiísimo Evémero, que habiéndose atrevido a hablar largamente sobre los dioses, termina con que no existen en absoluto, sino que quiere que todo sea gobernado por puro azar» (Theoph. Ad Autol. 3, 7) ${ }^{13}$.

Teófilo muestra, pues, su rechazo hacia las doctrinas de Evémero y otros filósofos paganos considerados ateos, como Epicuro y Pitágoras, puesto que niegan la existencia de la religio de los dioses y «destruyen la providencia». Sin embargo, la argumentación de Teófilo en relación a los dioses del paganismo es claramente evemerística: «Los nombres de los dioses a quienes dices das culto, son nombres de hombres muertos» (Theoph. Ad Autol. 1, 9; y 2, 34) ${ }^{14}$. Para Teófilo -como para la doctrina evemerística-,

Chrétiens, SC 507, Paris, 2006. Para la trad. esp. de ambos textos, D. Ruiz Bueno, Padres Apologetas Griegos (s.II), BAC, Madrid, $1996^{3}$.

${ }^{9} \mathrm{La}$ condena específica de la divinización de Antínoo es recurrente en la literatura apologética (Theoph. Ad Autol. 3, 8; Clem. Alex. Protr. 4, 49, 1-2; Orig. C. Cels. 3, 36-37; 5, 38; 8, 61; Tert. Ad nat. 2, 10, 11 ).

${ }^{10}$ León de Pella, escritor y sacerdote de la época de Alejandro Magno. Sobre la problemática en la identificación de este escritor, vid. J. Pépin, op. cit., pp. 7-8. Para las citas de Taciano he seguido la ed. y trad. esp. de D. Ruiz Bueno, op. cit. .

${ }^{11}$ Las citas se harán según la ed. de B. Pouderon, op. cit., y la trad. esp. de D. Ruiz Bueno, op. cit..

${ }^{12}$ Athenag. Leg. 28. (B. Pouderon, op. cit., p. 176, n. 2).

${ }^{13}$ Las citas de Teófilo se harán según la ed. y trad. esp. de D. Ruiz Bueno, op. cit.

${ }^{14}$ De hecho, las imágenes de los dioses son consideradas por este autor como «representaciones de hombres muertos» (Ad Autol. 1, 10). 
la raíz del problema en la distinción entre hombres y dioses se sitúa en los relatos mitológicos: «Mientras estáis leyendo sus nacimientos, los consideráis como hombres; pero luego les dais nombres de dioses y les rendís culto, sin atender ni comprender que cuales leísteis que nacieron, tales efectivamente existieron» (Theoph. Ad Autol. 2, 2).

$\mathrm{Al}$ igual que sus predecesores, Teófilo caracteriza a los dioses de la mitología con la descripción de sus nacimientos y muertes, su descendencia, o el sometimiento a las pasiones, debilidades y sufrimientos, propias de los hombres (Theoph. Ad Autol. 1, 9$10 ; 2,2-3 ; 2,5-7 ; 2,33-34 ; 2,36$.). La actitud de Teófilo ejemplifica la de una buena parte de los apologistas con respecto a Evémero. Por un lado, el desprecio hacia sus doctrinas, calificadas como ateas e irreligiosas. Por otro lado, a pesar de este rechazo, la falta de escrúpulos a la hora de utilizar sus argumentos en la refutación del paganismo. Clemente de Alejandría ofrece la perspectiva contraria. No sólo recurre al modelo de argumentación de Evémero sino que presenta una imagen favorable de él y de otros que, como él, rechazaron la existencia de los dioses:

Por esto [...] me sorprende ver de qué forma han llamado ateos a Evémero de Agrigento, a Nicanor de Chipre, a Diágoras e Hipón de Melos y con éstos a aquel cireneo (de nombre Teodoro) y a otros muchos que vivían con sensatez y se dieron cuenta con mayor agudeza que los demás hombres del error que existía en relación con estos dioses. Aunque no conocieron la verdad misma, sospechaban, sin embargo, el error, lo que precisamente hace germinar una semilla, no pequeña, que vivifica el fuego del entendimiento en su camino hacia la verdad» (Clem. Alex. Protr. 2, 24, 2) ${ }^{15}$.

Para Clemente estos filósofos ${ }^{16}$, con sus planteamientos ateos, se aproximan mejor a la verdad (del cristianismo) que el resto de los paganos, revelando que los dioses venerados por los hombres no tienen nada de divino: «Sus patrias, sus oficios, sus vidas e incluso sus muertes os muestran que se trata de hombres» (Clem. Alex. Protr. 2, 29, 1). En el Contra Celso Orígenes no menciona el nombre de Evémero, aunque el debate que establece con Celso en torno a esta cuestión gira alrededor de la idea central de esta doctrina: algunos hombres han sido venerados como dioses por sus conciudadanos en agradecimiento a los beneficios reportados a la comunidad (Orig. $C$. Cels. 3, 22-43) $)^{17}$. Los cristianos rechazan esta creencia porque consideran que la condición divina es incompatible con el carácter mortal de los hombres. El discurso de Orígenes presenta algunas particularidades. La más importante es que, al recoger el testimonio de Celso, el apologista deja en evidencia la censura de los paganos con

\footnotetext{
${ }^{15}$ Ed. de C. Mondésert y A. Plassart, Clément d'Alexandrie. Le Protreptique, SC 2, Paris, $1976^{2}$, y trad. esp. de M.C. Isart Hernández, Clemente de Alejandría. Protréptico, Madrid, 1994.

${ }^{16}$ De todos los filósofos mencionados, el más conocido es Evémero, de quien toma nombre esta teoría. Nicanor o Nicágoras de Chipre fue un gramático de la época de Adriano. Teodoro de Cirene es conocido por sus opiniones demoledoras acerca de la divinidad y de ciertos valores humanos, como la amistad. Hipón, citado junto a Diágoras, no es de Melos; es posible, que fuera originario de Samos. Diágoras de Melos, llamado el ateo, dedicó una de sus obras a la condena del culto frigio y, por extensión, de los dioses paganos.

${ }^{17}$ Ed. de M. Borret, Origène. Contre Celse, 4 vols., SC 132, 136, 147 y 150, Paris, 1967-1969, y trad. esp. de D. Ruiz Bueno, Orígenes. Contra Celso, BAC, Madrid, $2001^{3}$.
} 
respecto a la actitud cristiana: esas creencias que los cristianos reprochan a los griegos son las mismas que ellos practican cuando defienden la divinidad de Jesús, cuya muerte es reconocida y aceptada por todos (Orig. C. Cels. 3, 22). El modelo de argumentación de Orígenes se caracteriza, precisamente, por contraponer la figura de Jesús a la de los hombres considerados divinos entre los griegos. Para ello, utiliza los mismos argumentos que sus predecesores. Sin embargo, el primer reproche que Orígenes dirige contra Celso se apoya en la ambigüedad de éste con respecto a las propias creencias paganas: «Celso, muy astutamente, ni afirmó paladinamente no dar culto a ésos como a dioses, pues temía lo que pensarían sus lectores, que lo tendrían por ateo de haber proclamado lo que le parecía verdad, ni tampoco pretendió tenerlos él personalmente por dioses» (Orig. C. Cels. 3, 22).

La recriminación de ateísmo expuesta por Orígenes recuerda la de los intelectuales paganos con respecto a los planteamientos evemerísticos ${ }^{18}$. Entre los apologistas latinos, Minucio Félix es el primero en mencionar a Evémero de forma explícita:

Lee los escritos de los historiadores y de los sabios: comprobarás lo mismo que yo. Evémero enumera a los que han sido tenidos por dioses, ya sea a causa de su fuerza o de su función, relata sus nacimientos, sus lugares de origen y sus sepulcros y los va distribuyendo por las diferentes provincias, y eso lo hace con Júpiter de Dicte, Apolo de Delfos, Isis de Faros y Ceres de Eleusis (Min. Fel. Oct. 21, 1) ${ }^{19}$.

Minucio Félix no se cuestiona la doctrina o el pensamiento de Evémero y utiliza las obras de éste como una fuente de consulta, o como un testimonio adicional, en su refutación acerca de los dioses del paganismo. Las teorías evemerísticas -como cualquier otra forma de interpretación pagana que sirva a éste propósito- son utilizadas por Minucio Félix para demostrar la naturaleza humana de las divinidades paganas. El mismo análisis que ofrece Evémero acerca de Júpiter, Apolo, Isis o Ceres, puede aplicarse al resto de los dioses. No obstante, Minucio Félix considera que la esencia de la doctrina evemerística radica, no tanto en la demostración de esta naturaleza humana, como en la explicación que ofrece de esta confusión de identidades, es decir, adjudicar un carácter divino a simples seres mortales. La respuesta a esta pregunta no es otra que el temor, el respeto o la admiración que estas figuras despertaron entre sus conciudadanos, así como una muestra de agradecimiento por los bienes que pudieron reportarles en el pasado. Para confirmar este argumento, Minucio recurre a otros testimonios paganos (Pródico de Ceos, Perseo de Citio o la supuesta Carta de Alejandro a su madre) (Min. Fel. Oct. 21, 2-3).

\footnotetext{
${ }^{18}$ La misma idea sobre el ateísmo de Celso, aunque descrita como epicureísmo, en C. Cels. 3, 35. Frente a la actitud de respeto mostrada por Clemente de Alejandría en relación a los filósofos ateos, Orígenes rechaza por completo este modelo de pensamiento. El apologista sostiene que deben ser leídos todos los autores, con independencia de su tendencia religiosa o sus planteamientos filosóficos, a excepción de los ateos (Orig. Ep. Gr. Thaum. 13).

${ }^{19}$ Ed. de J. Beaujeu, Minucius Felix. Octavius, Paris, 1974², y trad. esp. de V. Sanz Santacruz, Minucio Félix. Octavio, Madrid, 2000.
} 
Tertuliano desarrolla esta misma cuestión en el capítulo undécimo del Apologético, aunque los argumentos son algo diferentes a los de Minucio Félix y los apologistas griegos. Tertuliano formula su rechazo a la divinización de los seres humanos en clave teológica, profundizando en aquellos aspectos relacionados con la concepción de la divinidad. Dios, en su perfección, es el único que tiene la capacidad de otorgar el carácter divino. «Está claro además que, si ellos mismos hubieran podido hacerse dioses, nunca hubieran sido hombres estando en su mano la facultad de procurarse mejor condición» (Tert. Apol. 11, 3) ${ }^{20}$. Dado que no necesita de nada, puesto que la creación, según el testimonio de los propios paganos, es anterior a estos supuestos dioses, no tiene sentido que lleve a cabo este acto (Tert. Apol. 11, 2-6). Los hombres no deben ser divinizados en señal de agradecimiento por los descubrimientos que han aportado a la humanidad: «lo que existía no se atribuye a quien lo descubrió sino a quien lo hizo, pues existía antes de ser descubierto» (Tert. Apol. 11, 7); y tampoco deben serlo por sus méritos. En primer lugar porque su conducta, recogida en la tradición mitológica, es inmoral, y en segundo porque siguiendo este principio, otros individuos, mucho más dignos, no han sido divinizados (Tert. Apol. 11, 10-16). No obstante, es cierto que el punto de partida para esta argumentación sigue siendo la doctrina evemerística, puesto que Tertuliano acepta como un hecho consumado que los dioses del paganismo son simples seres mortales: «En lo que respecta a vuestros dioses, únicamente veo los nombres de algunos muertos hace ya tiempo, y oigo leyendas, y conozco las ceremonias a través de las leyendas» (Tert. Apol. 12, 1) ${ }^{21}$. Aunque Tertuliano no alude de forma explícita a la figura de Evémero, se hace eco de sus planteamientos cuando expone su rechazo a la acusación de ateísmo, dirigida contra los cristianos por su negativa a participar en los cultos tradicionales en honor del emperador y los dioses (Tert. Apol. 27, 1). De forma categórica, afirma:

A vuestros dioses hemos dejado de darles culto desde el momento en que sabemos que no son dioses [...] Apelamos y acudimos a vuestra conciencia; que ella nos juzgue y ella nos condene si puede decir que todos esos dioses vuestros no han sido hombres (Tert. Apol. 10, 2-3).

Como los apologistas anteriores, Tertuliano se apoya en los planteamientos de Evémero para demostrar la condición humana de los dioses paganos, describiendo sus orígenes, nacimientos, hazañas, e incluso, sus lugares de enterramiento (Tert. Apol. 10, 4-5). Aunque sin aludir a Evémero, Cipriano de Cartago aborda esta misma cuestión al comienzo de su tratado Los ídolos no son dioses. Su exposición sigue el modelo de la argumentación empleada por Tertuliano y Minucio Félix. No obstante, a diferencia de éstos, el obispo de Cartago incide sobre uno de los aspectos concretos de la

${ }^{20}$ Ed. de J.-P. Waltzing, Tertullien. Apologétique, Paris, $1971^{3}$, y trad. esp. de C. Castillo García, Tertuliano. Apologético. A los gentiles, Madrid, 2001.

${ }^{21}$ Sobre el uso específico de los planteamientos de Varrón para expresar el rechazo del evemerismo en Tertuliano, vid. J.-M. Vermander, «La polémique de Tertullien contre les dieux du paganism», RSR 53 (1979) pp. 92 ; 112-114 y 116; y T.D. Barnes, Tertullian. A Historical and Literary Study, Oxford, 1971, p. 105. 
doctrina evemerística: la teoría que identifica a los dioses del paganismo con los reyes y gobernantes de las naciones quienes, una vez fallecidos, habrían alcanzado la condición divina como recompensa a las hazañas en beneficio de sus conciudadanos (Cypr. Quod idola , 1-4 $)^{22}$. Tanto Arnobio como Lactancio aluden de forma explícita a las teorías de Evémero para demostrar la condición humana de los dioses. Ambos no sólo mencionan su nombre sino también el título de su obra, la Historia Sagrada. Arnobio, de hecho, informa acerca de la traducción de ésta realizada por Ennio (Arnob. Adv. Nat. 4, 29; Lact. Div. Inst. 1, 11, 33; 1, 17, 10 ${ }^{23}$. Como ya hiciera Clemente de Alejandría, Arnobio complementa el pensamiento de Evémero con el de otros filósofos paganos (entre otros, Nicágoras de Chipre, León de Pella, Teodoro de Cirene, Hipón y Diágoras de Melos), para concluir, después de analizar las ocupaciones, acciones y origen de las divinidades paganas, que «todos esos que nos presentáis y que llamáis dioses han sido hombres» (Arnob. Adv. Nat. 4, 29) ${ }^{24}$. Lactancio, por su parte, utiliza el testimonio de Evémero para describir la figura de Júpiter:

Evémero, antiguo autor de la ciudad de Mesena, recoge las hazañas de Júpiter y de todos los demás considerados dioses, y compuso una historia a partir de los epígrafes e inscripciones sagradas que se encontraban en los viejos templos y sobre todo en el templo de Júpiter Trifilio; la inscripción del frontispicio de este templo indicaba que la columna de oro que allí estaba había sido colocada por el propio Júpiter; en ella escribió él sus propias hazañas para que sirviera de recuerdo de sus hechos en la posteridad (Lact. Div. Inst. 1, 11, 33).

Lactancio sostiene que, aunque los poetas eran conscientes de la humanidad de los personajes retratados, optaron por afirmar su divinidad con la intención de ensalzar su recuerdo (Lact. Div. Inst. 1, 11, 17).

\section{LA DIVINIZACIÓN DEL SOBERANO Y EL CULTO IMPERIAL}

La literatura apologética recupera el argumento de la divinización de los soberanos para exponer su crítica contra los dioses del paganismo. Justino vincula directamente este modelo interpretativo con la creencia pagana de que, tras la muerte, los

\footnotetext{
${ }^{22}$ Ed. y trad. esp. de J. Campos, Obras de San Cipriano. Tratados. Cartas, Madrid, 1964.

${ }^{23}$ Para las citas de Lactancio he seguido la ed. de P. Monat, Lactance. Institutions Divines, Livre I, Livre II, Livre IV, Livre V, vol. 1, Livre V, vol.2, Paris, 1986-2000² ; C. Ingremeau, Lactance Institutions Divines, Livre VI, Paris, 2007; S. Brandt, L. Caeli Firmiani Lactantii opera omnia: Divinae institutione et epitome divinarum institutionum, CSEL 19, Wien, 1890, y la trad. esp. de E. Sánchez Salor, Lactancio. Instituciones Divinas, Vol. 1: Libros I-III; Vol. 2: Libros IV-VII, Madrid, 1990. Para las citas de Arnobio, se sigue la ed. de H. Le Bonniec, Arnobe. Contre les Gentiles. Livre I, Paris, 1982; J. Champeaux, Arnobe. Contre les Gentils. Livre III, Paris, 2007; A. Reifferscheid, Arnobius. Adversus Nationes livri VII, CSEL 4, Wien-Leipzig, 1875, y la trad. esp. de C. Castroviejo Bolívar, Arnobio de Sicca. Adversus Nationes. En pugna con los gentiles, Madrid, 2003.

${ }^{24}$ Arnobio es el primer escritor cristiano que alude a la traducción latina de Ennio. Aunque la doctrina de Evémero era ampliamente conocida en la época, probablemente la mayor parte de los apologistas no dispuso de la fuente original, sino que manejó la traducción de Ennio.
} 
gobernantes, «a quienes tenéis siempre por dignos de la inmortalidad» (Just. 1 Apol. 21,3 ), adquieren la condición divina: «las mismas imágenes de vuestros emperadores, cuando mueren, las consagráis por esta figura, y los llamáis dioses en vuestras inscripciones» (Just. 1 Apol. 55, 7). Taciano también se apoya en la idea de la divinización de los gobernantes para mostrar su rechazo hacia el culto imperial. El concepto de divinidad que tienen los cristianos es incompatible con estos rituales de veneración, aceptados entre los paganos, incluso por aquéllos que niegan la existencia de sus dioses: «la junta entera de vuestros muchos dioses nada es, y, aún cuando el negador de ellos, Epicuro, vaya delante con su tea, yo no doy a los príncipes un culto superior al de Dios» (Tat. Orat. 27). Aunque estrechamente relacionadas, se trata de dos cuestiones diferentes en el discurso cristiano. Las referencias de Justino y Taciano aluden a la práctica del culto al emperador. El rechazo de los cristianos a participar en este ritual, interpretado como un gesto incívico y de deslealtad hacia el emperador, fue uno de los motivos de las persecuciones ${ }^{25}$. Los apologistas cristianos formulan su defensa para tales imputaciones con una argumentación doble. Por un lado, la teoría que presenta al cristiano como modelo de ciudadano ideal en contraposición a la incorrecta actitud cívica de los paganos. Por otro lado, la explicación que justifica su rechazo a participar en dichas ceremonias. La clave reside en la condición humana de los emperadores. Esta condición se convierte en un elemento incompatible con la interpretación cristiana de la divinidad. De ahí la insistencia de los apologistas en demostrar su respeto y lealtad a la autoridad, pero no su adoración al emperador como si de un dios se tratara ${ }^{26}$. Los paganos malinterpretan este respeto debido a los emperadores, haciéndoles objeto de culto y divinizándolos. El argumento en el que se apoyan los apologistas para desacreditar a los dioses de la mitología tradicional es el mismo que el de Evémero. Esto explica que, aunque con fines diferentes, los razonamientos expuestos para ambas cuestiones coincidan y que, con frecuencia, aparezcan entrelazados a lo largo del discurso.

El primer autor que utiliza la divinización de los gobernantes para explicar la condición de los dioses del paganismo es Atenágoras, quien formula su teoría apoyándose

\footnotetext{
${ }^{25}$ Para una introducción a esta cuestión, vid. R. MacMullen, Enemies of the Roman Order. Treason, Unrest, and Alienation in the Empire, Cambridge-London, $1975^{2}$; C. González Román, «Teoría política y aculturación en los apologetas griegos de fines del reinado de Marco Aurelio», A. González Blanco y J.M. Blázquez Martínez (eds.), Cristianismo y aculturación en tiempos del Imperio Romano. Antigüedad y Cristianismo 7, Murcia, 1990, pp. 105-114; J.W. Hargis, Christian Exclusivism and the Formation of Early Anti-Christian Discourse in Celsus, Porphyry and Julian, Ann Arbor, 1998; F. Millar, «The Imperial Cult and the Persecutions», Rome, the Greek World, and the East, vol. 2: Government, Society, and Culture in the Roman Empire, London, 2004 (reimpr. 1973), pp. 298-312; M. Sordi, «L’homo romanus: religión, droit et sacré», J.Ries, A. Motte y N. Spineto (eds.), Les Civilisations méditerranéennes et le sacré, Turnhout, 2004, pp. 285-310; A.R. Birley, "Attitudes to the State in the Latin Apologists», A. Wlosok y F. Paschoud (eds.), op. cit., pp. 249-289; R. González Salinero, Las persecuciones contra los cristianos en el Imperio Romano. Una aproximación crítica, Madrid, 2005.

${ }^{26}$ Just. 1 Apol. 17, 3; Mel. Apol. en Eus. H.E. 4, 26, 5-8; Athenag. Leg. 1, 3; 3, 2; 37, 2-3; Theoph. Ad Autol. 1, 11; 2, 25; 3, 14; Tert. Apol. 24, 4; 30, 1 y 4-5; 32, 2; 36, 2; Ad Scap. 2 y 5; Cypr. Ad Dem. 20; Arnob. Adv. Nat. 4, 36; etc.
} 
en los testimonios de Heródoto (Athenag. Leg. 28, 1-3) ${ }^{27}$, Apolodoro ${ }^{28}$ y en la carta de Alejandro Magno a su madre. A partir de las supuestas conversaciones que aquéllos mantuvieron con los sacerdotes egipcios de Heliópolis, Menfis y Tebas se desprende que los dioses egipcios no solo fueron hombres sino que gobernaron el país en otro tiempo:

Por donde se ve que a los primeros reyes, de origen celeste como eran, parte por ignorancia de la verdadera piedad para con la divinidad, parte por gratitud de su mando, los tuvieron por dioses junto con sus mujeres [...] ¿A quiénes pudiera creérseles mejor al decir esto que a quienes por sucesión de familia, el hijo del padre, heredan el sacerdocio y juntamente la historia? Porque no es verosímil que mientan los zácoros, que tienen interés en exaltar a sus ídolos, al presentarlos como hombres (Athenag. Leg. 28, 4-5).

Según Heródoto, o la interpretación que ofrece Atenágoras de su pensamiento, aquellos grandes sacerdotes, o zácoros, que nos transmiten el secreto sobre la condición humana de los dioses, no pertenecerían a esta dinastía supuestamente divina, sino que sus últimos representantes serían Osiris y Horus. Para Atenágoras, la prueba que confirma el testimonio de los sacerdotes egipcios se encuentra en los linajes genealógicos de los grandes personajes históricos, como Alejandro Magno o Hermes Trismegisto, quienes se esfuerzan por relacionar su pasado con el de los dioses (Athenag. Leg. 28, 6-7 ${ }^{29}$. De este modo, las ceremonias rituales egipcias que describe Heródoto no son más que reproducciones simbólicas de los sufrimientos que aquéllos padecieron como hombres (Athenag. Leg. 28, 8-10) ${ }^{30}$. No obstante, Atenágoras confunde personajes históricos con héroes míticos o legendarios, incluyendo no sólo figuras de gobernantes, sino también los nombres de algunos atletas que fueron divinizados por sus triunfos deportivos y considerados dioses por ello (Athenag. Leg. 14, 1) ${ }^{31}$. Teófilo de Antioquía sostiene esta misma opinión sobre el linaje humano de ciertas divinidades, cuando, a partir del testimonio del historiador Sátiro, expone en detalle el árbol genealógico de Ptolomeo Filopátor (Theoph. Ad Autol. 2, 7). Clemente de Alejandría ofrece

${ }^{27}$ Hdt. 2, 3, 1-2; 2, 90, 1-2; 2, 144, 1-2; 2, 156, 4-6.

${ }^{28}$ Mitógrafo del siglo II a.C., distinto del autor de la Bibliotheca.

${ }^{29}$ Alejandro Magno había sido reconocido como hijo de Ammón (Zeus) (Plu. Alex. 27, 3-6 y 28, 1-3; Hdt. 2, 59, 2). Hermes Trismegisto fue identificado con el dios Thot de los egipcios (Theut) (Pl. Phdr. 274, c-e; Phlb. 18 , b-d), aunque aquí aparece descrito como un hombre, iniciador de un movimiento religioso. Se le atribuye la composición de un tratado sobre dichos herméticos (Aug. Civ. Dei. 8, 23, 1; 8, 26, 1-3). Sobre esta cuestión, vid. B. Pouderon, op. cit., p. 180, n. 1.

${ }^{30}$ Cf. Hdt. 2, 86, 2; 2, 170, 1-2; 2, 171, 1 .

${ }^{31}$ Entre los diferentes personajes mencionados aparecen: personalidades históricas como Teágenes (Paus. 6, 11, 2-9; Luc. Deor. Con. 12), Lisandro (Paus. 6, 3, 14-15; Plu. Lys. 18, 1-5), Filipo, hijo de Butacidas (Hdt. 5, 47, 1), Onesilao (Hdt. 5, 114, 1-2) y Amílcar (Hdt. 7, 167, 1-2); entre las figuras legendarias, Celeo y Metanira (Paus. 1, 39, 2; 2, 14, 2-3), Menelao (Isoc. Helen. 62-63; Paus. 3, 19, 9), Héctor (Paus. 9, 18, 5), Aristeo (Pind. Pyth. Od. 9, 59-66; Diod. Sic. 4, 82, 5; Verg. Georg. 4, 281-333), Medea (Pind. Pyth. Od. 4, 8-16; Ap. Rhod. 4, 811-815; Paus. 2, 3, 6 y 8-11) y Niobe (Soph. Elect. 150-152; Antig. 824-832). Para una introducción a estos personajes, vid. B. Pouderon, op. cit., pp. 319-324. 
en el Protréptico varios ejemplos que ilustran esta confusión de adjudicar la categoría de divino a los gobernantes. El primero de ellos se relaciona con el culto, entre los egipcios, a Serapis. En su exposición sobre el origen de la estatua de esta divinidad, Clemente presenta las diferentes versiones que recoge la tradición (Clem. Alex. Protr. 4, 48, 2-3 ${ }^{32}$. Entre las múltiples explicaciones se incluye la de Atenodoro, según la cual la estatua de Serapis, elaborada con piedras preciosas, fue un encargo del rey de Egipto, Sesostris, después de sus campañas militares contra los griegos. La orden consistía en trabajar de forma artística la estatua de Osiris, el abuelo de Sesostris. En el proceso de elaboración, el artista Briaxis, «disolvió todo con las tinturas que le quedaban de las honras fúnebres de Osiris y Apis» (de cuya unión procede el nombre de Serapis ${ }^{33}$ ). Para Clemente, el relato de Atenodoro demuestra la relación familiar entre Sesostris y Osiris, al que presenta como su abuelo, y la consiguiente desacreditación del carácter divino de Serapis (Clem. Alex. Protr. 4, 48, 4-6) ${ }^{34}$. El apologista sostiene que son, precisamente, las representaciones artísticas de las divinidades, la causa fundamental que explica el comienzo de esta práctica de adoración de los gobernantes entre los súbditos (Clem. Alex. Protr. 4, 53, 4-6; 4, 54, 1 y 5$)^{35}$.

Entre los numerosos ejemplos de divinización de gobernantes mencionados en el Protréptico destacan los de Ceyx y su esposa Alcíone (equiparados con Zeus y Hera) (Clem. Alex. Protr. 4, 54, 1) ${ }^{36}$, Ptolomeo IV y Mitríades del Ponto (asimilados a Dioniso), y el de Alejandro Magno (identificado como el hijo de Ammón / Zeus) (Clem. Alex. Protr. 4, 54, 2; 10, 96, 4; 10, 97, 1). Clemente señala que la práctica de la deificación humana no es un fenómeno exclusivo de los gobernantes, y que del mismo modo pueden citarse otros casos de individuos particulares, que «se honraron a sí mismos con denominaciones divinas» (Clem. Alex. Protr. 4, 54, 3-6) ${ }^{37}$. Clemente califica a quienes siguen estas prácticas de adoración como «coreutas impíos de la superstición» (Clem. Alex. Protr. 10, 96, 4).

\footnotetext{
${ }^{32}$ Una de las versiones sostiene que la estatua de Serapis fue originalmente una imagen de Plutón, que los sinopeos regalaron al rey de Egipto, Ptolomeo Filadelfo, en señal de agradecimiento (aunque Plutarco ofrece una explicación diferente: De Is. et Os. 28). Una segunda versión considera que la estatua tiene su origen en el Ponto y que de allí llegó a Alejandría. La tercera, que fue un regalo de los seléucidas, y la cuarta, la que presenta Atenodoro (vid. infra).

${ }^{33}$ Esta es la base para la explicación etimológica que ofrece Clemente acerca de Serapis: «la puesta en común de las honras fúnebres y de la obra del sepulcro, Osirapis es una síntesis de Osiris y Apis» (Clem. Alex. Protr. 4, 48, 6). Según Plutarco, el nombre de Osiris, procede de la unión de hosios (en relación con el inframundo y la muerte) y hieros (vinculado al cielo y lo sagrado), de modo, que se trataría de una divinidad del cielo y del infierno (Plu. De Is. et Os. 61).

${ }^{34}$ Athenod. Frag. 4 [F.H.G. Vol. 3, p. 487-488]; Plu. De Is. et Os. 28.

${ }^{35}$ Los ídolos no reflejan de forma apropiada los rasgos de las divinidades. Clemente atribuye a Artajerjes el origen de la idolatría y la adoración de los dioses a través de imágenes con forma humana (Protr. 5, 65, 3; Beros. Frag. 16 [F.H.G. Vol. 2, pp. 508-509]).

${ }^{36}$ Irritados por esta actitud, los dioses los transformaron en aves (Apollod. Bibl. 1, 7, 4), aunque Ovidio señala que su metamorfosis fue por amor (Met. 11, 410-748).

${ }^{37}$ Entre los ejemplos citados destacan: el médico Menécrates, designado como Zeus (Plu. Ages. 21, 5; Apoph. 191a); el gramático Alexarcos, equiparado al sol; Nicágoras, como Hermes; Filipo de Pelas que, pese a sus defectos, es adorado por sus conciudadanos (Dem. De cor. 67-68); y Demetrio, a quien se le dedica un santuario, varios altares, e incluso, se le preparó una supuesta boda con la imagen de Atenea (Plu. Demetr. 10, 2-4 y 26, 1-3).
} 
Entre los apologistas latinos, Minucio Félix ofrece una exposición semejante sobre el origen de la divinización de los reyes:

De modo semejante creyeron también en los dioses nuestros predecesores, ingenuos, crédulos y de una simplicidad ignorante. Cuando devotamente daban culto a sus reyes y, una vez muertos, deseaban verlos en efigie, cuando ardientemente anhelaban retener su memoria gracias a las estatuas, lo que al principio había sido un simple consuelo, acabó convirtiéndose en algo sagrado (Min. Fel. Oct. 20, 5).

El autor considera que la costumbre de venerar, una vez muertos, a los fundadores de cada nación, a los jefes ilustres, a los reyes poderosos o a quienes hubiesen aportado algún beneficio a la comunidad, es una forma de honrar a los difuntos y de dar ejemplo entre las generaciones futuras, pero no necesariamente la creencia en el carácter divino de los mismos (Min. Fel. Oct. 20, 6; 24, 1). Entre los casos concretos de deificación humana, Minucio Félix menciona a Rómulo, fundador de Roma, y a Juba II, rey de Mauritania (Min. Fel. Oct. 24, 1) ${ }^{38}$. En los mismos términos se expresa Cipriano de Cartago al comienzo de su tratado Los ídolos no son dioses, aludiendo al caso de Rómulo y a las prácticas mauritanas (Cypr. Quod idola, 1; 2 y 4). Cipriano sostiene que estos actos de veneración eran una forma «de conservar la memoria de sus antepasados» (Cypr. Quod idola, 3$)^{39}$.

El discurso de Tertuliano es algo diferente al de Minucio Félix y Cipriano. Aunque también menciona el ejemplo de Rómulo (Tert. Apol. 21, 23), su exposición se dirige hacia otros aspectos. Tertuliano se sirve de este argumento para formular su condena sobre el origen de la religión romana. En respuesta a las acusaciones dirigidas contra los cristianos, como responsables de los males acontecidos en el Imperio, el apologeta sostiene que la historia demuestra que la religión pagana ha conocido su desarrollo en función del progreso del poder político (Tert. Apol. 25, 10-13) ${ }^{40}$. Así, en su relato se entremezclan diferentes tipos de divinidades, aquéllas que ejercieron un gobierno terrenal (como Saturno y Júpiter) y las que no lo hicieron (como Estérculo). Puesto que la capacidad de ejercer el poder terrenal es una concesión divina ${ }^{41}$, los relatos mitológicos están llenos de incoherencias al presentar a los futuros dioses sometidos al poder de quienes no lo son. Una vez demostrado que la divinización de los seres humanos no es una práctica racional, la segunda parte de su argumentación se centra en que en el caso de la figura del emperador se trata incluso de un gesto indigno, evocando dos costumbres romanas, la ceremonia del triunfo, en la que se

\footnotetext{
${ }^{38}$ Sobre la divinización de Rómulo: Liv. 1, 15, 6-8; 16, 1-8.

${ }^{39}$ Aquí Cipriano se apoya en el testimonio de la Carta de Alejandro a su madre.

40 Tertuliano destaca que una buena parte de los cultos romanos fue introducida por el rey Numa Pompilio y que, en sus orígenes, se desarrollaban de una forma mucho más modesta (Cic. De Rep. 2, 14, 27). La misma idea sobre el papel de Numa Pompilio en Apol. 21, 29-30.

${ }^{41}$ Tert. Apol. 32, 3; 33, 1; 49, 4-6; Ad Scap. 2. El reconocimiento cristiano de la autoridad terrenal es un principio de la doctrina paulina ( $c f . R m .13,1-2 ; 1$ Tm. 2, 1-2; Tt. 3, 1; 1 P. 2, 13-17; etc.). El origen divino del poder de los reyes y gobernantes también aparece expresado en el Antiguo Testamento ( $S b$. 6, 1-3; Pr. 24, 2122 ; etc.).
} 
recuerda al emperador su condición humana y la apoteosis, a la muerte del césar (Tert. Apol. 33, 3-4 $)^{42}$. Hacerlo con anterioridad, es decir, en vida, es un gesto de mal augurio que puede interpretarse como una incitación a su muerte prematura ${ }^{43}$. Tanto Minucio Félix como Tertuliano consideran que las prácticas de adoración a los gobernantes, como si fueran dioses, no son formas apropiadas para mostrar respeto (Min. Fel. Oct. 29, 5). En realidad, es una práctica que se desarrolla «en contra de su voluntad, pues desean perseverar en su condición humana, temen convertirse en dioses e, incluso ya viejos, lo rechazan» (Min. Fel. Oct. 24, 2; Tert. Apol. 33, 3). Tertuliano sostiene, además, que los propios emperadores reconocen la autoridad del Dios supremo, de quien admiten que depende su poder (Tert. Apol. 30, 1).

\section{EL CARÁCTER MORTAL DE LOS DIOSES}

La prueba que mejor demuestra la condición mortal de los dioses del paganismo se encuentra en la descripción que ofrecen los relatos mitológicos acerca de los diferentes tipos de muerte que éstos han padecido. Los tres ejemplos emblemáticos para la demostración de estas teorías son los relatos acerca de las muertes de Asclepio / Esculapio $^{44}$, fulminado por el rayo de Zeus, Heracles / Hércules ${ }^{45}$, arrojándose él mismo al fuego, y Dioniso / Líber ${ }^{46}$, degollado y descuartizado por los Titanes. Arístides

\footnotetext{
42 Tertuliano distingue entre Dominus, identificado con la divinidad y dominus, en el sentido corriente del término, aunque diferente del de Pater patriae e Imperator, títulos más apropiados para denominar a la autoridad terrenal (Apol. 33, 3-4; 34, 1-3). Augusto y Tiberio rechazaron el título de Dominus (Suet. Aug. 53, 1; Tib. 27; Tac. Ann. 2, 87; Dio Cass. 57, 8, 1-2), que sólo fue admitido años más tarde por Calígula, Domiciano y Cómodo. Sorprende que Tertuliano evoque esta cuestión cuando Septimio Severo, bajo cuyo mandato escribe el apologista, también recibió una denominación semejante: Dominus noster. Tertuliano afirma que los cristianos no deben participar en las ceremonias de juramento por los genii, a quienes identifica con daemones, sino que están obligados a conjurarlos para expulsarlos (Apol. 28, 4; 32, 2-3; 35, 10; Ad Nat. 1, 10, 29-33). Evoca igualmente la ceremonia del triunfo, que en época imperial sólo se concede a los Principes, con el propósito de demostrar que los propios emperadores aceptan su condición humana (Plin. H.N. 28, 4).

${ }^{43}$ El propio Nerón rechazó la propuesta del cónsul Cerial Anicio de que se le erigiera un templo por esta misma razón (Tac. Ann. 15, 74, 3).

${ }^{44}$ Arist. Apol. 10, 5-6; Just. 1 Apol. 21, 2; Athenag. Leg. 29, 2; Theoph. Ad Autol. 1, 13; Clem. Alex. Protr. 2, 30, 1-2; Orig. C. Cels. 3, 22-23; Tert. Apol. 14, 5; Min. Fel. Oct. 22, 7; Cypr. Quod idola, 2; Arnob. Adv. Nat. 1, 41; 4, 24; 7, 44. Sobre la muerte de Asclepio / Esculapio: Plin. H.N. 29, 1, 2-3; Verg. Aen. 7, 765-776. A1 matar a los Cíclopes, Apolo consigue resucitar a su hijo, quien comienza entonces a recibir honores divinos (Apollod. Bibl. 3, 10, 3-4; Diod. Sic. 4, 71, 1-3; Luc. Dial. Deor. 15[13]; Sext. Emp. Adv. Math. 1, $260-262$

45 Arist. Apol. 10, 9; Just. 1 Apol. 21, 2; Tat. Orat. 21 (Taciano confunde a Asclepio con Heracles); Athenag. Leg. 29, 1; Theoph. Ad Autol. 1, 9; 1, 13; Clem. Alex. Protr. 2, 30, 7; Tert. Apol. 15, 5; Min. Fel. Oct. 22, 7; Cypr. Quod idola, 2; Arnob. Adv. Nat. 1, 36; 1, 41; 4, 25. Para este mito: Pind. Nem. Od. 3, 20-29; Soph. Trach. 555-632; 680-813 y 1157-1256; Diod. Sic. 4, 38, 1 - 39, 1; Apollod. Bibl. 2, 7, 7; Cic. De nat. deor. 3, 16, 41; 3, 28, 70; Sen. Her. Oet. 485-583; 716-739; 789-842; 1474-1497 y 1727-1755; Luc. Dial. Deor. 15[13].

${ }^{46}$ Arist. Apol. 10, 8; Just. 1 Apol. 21, 2; 54, 6; Tat. Orat. 8; Clem. Alex. Protr. 2, 17, 2; 2, 18, 1-2; 2, 23, 1; Orig. C. Cels. 3, 23; 4, 17; Arnob. Adv. Nat. 1, 41; 5, 19. Arístides y Justino describen la muerte de Dioniso, siendo adulto. No obstante, el mito al que aluden los apologistas posteriores es diferente. Clemente de Alejandría es el primero en ofrecer los detalles acerca del mismo: mientras Dioniso niño bailaba con los curetes fue
} 
incluye estos tres modelos e incorpora las muertes de Adonis (Arist. Apol. 11, 4) ${ }^{47}$, herido por un jabalí, y Atis (Arist. Apol. 11, 5[sy].) ${ }^{48}$. Arístides señala, además, que, entre los múltiples actos deshonrosos cometidos por los dioses, se incluye el asesinato de los padres. De manera que, mientras unos dioses aparecen descritos como parricidas, otros se convierten en las víctimas de tales afrentas y mueren «degollados o fulminados». En cualquier caso, ninguno de estos actos es propio de una divinidad (Arist. Apol. 9, 8-9; 13, 3 y 6; 13, 7). No obstante, Arístides adjudica de forma específica este error de interpretación, entre las divinidades y los seres mortales, a los egipcios. Esto explicaría la veneración que siente este pueblo por Isis y Osiris. Según el relato mitológico, éste último, incapaz de defenderse, padeció una muerte horrible a manos de su hermano Tifón, que lo degolló y descuartizó, esparciendo por Egipto las diferentes partes de su cuerpo. Arístides insiste en que ninguno de estos personajes fue capaz de «librarse a sí mismo de la muerte». Ni siquiera la diosa Isis pudo intervenir en la salvación de Osiris, limitándose a «llorar amargamente» la muerte de su marido y hermano. Sin embargo, Arístides señala que, pese a que tales sucesos son conocidos, «fueron tenidos por dioses por los insensatos egipcios» (Arist. Apol. Apol. 12, $2-3$ y $6[\mathrm{gr}])^{49}$. Justino alude, igualmente, a la variedad de sufrimientos y muertes padecidas por los dioses, «los hijos de Zeus» (Just. 1 Apol. 22, 3-4; 21, 2) ) $^{50}$. Taciano incorpora a su relato, además de los ejemplos citados, la muerte de Jacinto y señala que tales padecimientos y heridas son la prueba que demuestra el carácter mortal de las divinidades (Tat. Orat. 8) ${ }^{51}$. Como sus predecesores, Atenágoras menciona las muertes de Osiris, de Jacinto, de Asclepio y de Heracles, a partir de los relatos mitológicos (Athenag. Leg. 21, 6; 22, 8; 29, 1-2). Sin embargo, incorpora a su argumentación algunas expresiones de autores paganos, como Esquilo (Athenag. Leg. 21, 6) ${ }^{52}$,

engañado por los Titanes, hermanos de Cronos, quienes lo descuartizaron. A continuación, vertieron sus miembros en un caldero para cocinarlo y ofrecérselo a Hefesto. Sin embargo, Zeus descubrió el engaño y entregó el cadáver despedazado a Apolo para que lo enterrara en el Parnaso (Diod. Sic. 3, 62, 1-8; 5, 75, 4; Hyg. Fab. 155 y 167).

${ }_{47}$ Apollod. Bibl. 3, 14, 4; Plu. Quaest. conv. 4, 5, 3.

${ }^{48}$ Arístides no describe el modo en el que Atis pierde la vida. La alusión, además, únicamente aparece en la versión siríaca del texto.

${ }^{49}$ Isis encontró los restos del cuerpo de Osiris y, reuniéndolos, le devolvió la vida (Hdt. 2, 42; 2, 58-59; 2, 144; Strab. 17, 1, 23; Diod. Sic. 1, 13-23; Plu. De Is. et Os. 12-19; Apul. Met. 11, 12-18). Para una introducción al culto de Isis, Osiris y Serapis, vid. F. Cumont, Les Religions Orientales dans le Paganisme Romain, Paris, 1963 (reimpr. 19294), pp. 69-94; V. Tran Tam Tinh, «Sarapis and Isis», B.F. Meyer y E.P. Sanders (eds.), Jewish and Christian Self-Definition. vol. 3: Self-Definition in the Graeco-Roman World, London, 1982, pp. 101-117 y $207-210$.

${ }^{50}$ Se incluye la descripción de las muertes de Asclepio, Heracles y Dioniso (1 Apol. 54, 6).

${ }^{51}$ Jacinto muere a consecuencia de un golpe mientras jugaba con Apolo al disco. Algunas versiones del mito responsabilizan a Céfiro, dios del viento, de su muerte (Apollod. Bibl. 1, 3, 3; 3, 10, 3; Paus. 3; 3, 19, 4-5; Luc. Dial. Deor. 16[14]; Ov. Met. 10, 162-219).

${ }^{52}$ Atenágoras utiliza una expresión de Esquilo para aludir al hecho de que, pese a tratarse del favorito de Apolo, éste no pudo, con sus dotes adivinatorias, predecir la muerte de Jacinto (Aesch. Frag. 350 [Nauck p. 105]; Pl. Resp. 2, 383b). Sin embargo, el verso mencionado de Esquilo no está relacionado con la muerte de Jacinto, sino con la de Aquiles, y quien lamenta su muerte es su madre, la diosa Tetis (B. Pouderon, op. cit., p. 146, n. 1). 
Hesíodo o Píndaro (Athenag. Leg. 29, 2) ${ }^{53}$, que inciden en el carácter mortal de los dioses. Añade, además, a su narración el asesinato de Ifito (Athenag. Leg. 29, 1$)^{54}$ a

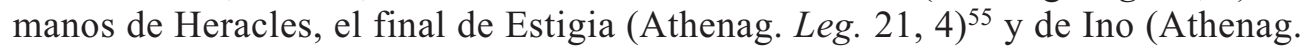
Leg. 29, 4) ${ }^{56}$, así como la mortalidad de Cástor, Pólux y Anfiareo (Athenag. Leg. 29, $4)^{57}$. La descripción que ofrece Teófilo de Antioquía sobre las muertes padecidas por los dioses es similar a la de Justino y Taciano y se limita a exponer brevemente los casos de Asclepio, Heracles, Jacinto, Osiris y del propio Zeus (Theoph. Ad Autol. 1, $9 ; 1,13 ; 2,3)$, aunque nunca se especifica el modo en el que muere Zeus. Por su parte Clemente de Alejandría, como Atenágoras, se apoya no solo en la tradición mitológica, sino también en el testimonio de otros escritores para describir la condición mortal de los dioses del paganismo (Clem. Alex. Protr. 2, 19, 1-4) ${ }^{58}$. Así, Píndaro y Eurípides son mencionados para el caso de Asclepio (Clem. Alex. Protr. 2, 30, 1 $2)^{59}$; Patroclo el turio, Sófocles y los poemas cipriacos completan el testimonio homérico en relación a los Dioscuros (Clem. Alex. Protr. 2, 30, 4-5) ${ }^{60}$; el testimonio de la Sibila se utiliza para confirmar que Serapis, «yace como un inmenso cadáver» en Egipto (Clem. Alex. Protr. 4, 50, 3) ${ }^{61}$; el poema de Calímaco sobre la tumba de Zeus en Creta para ratificar su muerte (Clem. Alex. Protr. 2, 37, 4) ${ }^{62}$; o el texto elegíaco del propio Hipón, quien se equipara a los dioses inmortales, demostrando así la condición humana de aquéllos (Clem. Alex. Protr. 4, 55, 1-2) ${ }^{63}$. El apologista alejandrino, de hecho, no describe la muerte de Heracles en términos mitológicos, sino que, por el contrario, afirma que su fallecimiento responde a un acto natural: «Este Heracles vivió cincuenta y dos años y terminó su vida recibiendo los honores funerarios en la pira del monte Eta» (Clem. Alex. Protr. 2, 30, 6-7). En tono irónico, Clemente alude a las muertes, en general, de los diferentes dioses paganos: «Cuántos Apolos hay también ahora, innumerables mortales y otros hombres sujetos a muerte, que se llaman poco más o menos con estos nombres dichos» (Clem. Alex. Protr. 2, 28, 4). Con esta forma despectiva de designar los nombres de los dioses en plural -también aplicada

\footnotetext{
${ }^{53}$ El apologista recurre al testimonio de Hesíodo y Píndaro para describir la muerte de Asclepio. Respecto a Hesíodo, el fragmento mencionado solo es conocido por Atenágoras (Hes. Frag. 125 [Rzach p. 177]). El pasaje de Píndaro presenta algunas variantes (Pyth. Od. 3, 96-98 y 100-105; citado de forma parcial por Platón, Resp. 3, 408b-c).

54 Hom. Od. 21, 36-38.

55 Aunque Hesíodo señala que Estigia era inmortal (Hes. Theog. 390-402).

56 Ino, hija de Cadmos, se precipita al mar junto al cadáver de su hijo Melicerte (Eur. Med. 1282-1290; Paus. 1, 44, 7-8; Menecr. Tyr. Frag. 6 [F.H.G. Vol. 2, p. 344]; Philosteph. Cyr. Frag. 37 [F.H.G. Vol. 3, p. 34]; Cic. De nat. deor. 3, 15, 39; 3, 19, 48; Tusc. 1, 12, 28; Ov. Met. 4, 512-542; Apollod. Bibl. 1, 9, 1-2; 3, 4, 3: arrojándose a una caldera de agua hirviendo).

57 Según la tradición mitológica, los hermanos gemelos Cástor (fallecido en combate) y Pólux (inmortal), los Dioscuros o Castores, consiguieron que Zeus les permitiera vivir alternativamente seis meses en este mundo y seis meses en el más allá (Pind. Pyth. Od. 11, 59-63).

58 Además de la muerte de Dioniso, Clemente alude al asesinato (fratricidio) de uno de los Coribantes.

${ }^{59}$ Pind. Pyth. Od. 3, 85-109; Eur. Alc. 3-4.

${ }^{60}$ Hom. Il. 3, 243.

61 Sibyll. Orac. 5, 654-658.

62 Callim. Hymn. in Jov. 8.

${ }^{63}$ Hippo, Frag. 2 [Diels p. 232].
} 
a Asclepio, Hermes y Hefesto (Clem. Alex. Protr. 2, 29, 1)-Clemente pretende restar valor a la condición divina de éstos y demostrar que se trata únicamente de hombres divinizados después de su muerte:

Los que adoráis vosotros, esos que fueron hombres en otro tiempo, murieron, sin embargo. El mito y el tiempo los honró. Se acostumbra a despreciar el presente por el trato continuo y, en cambio, lo que desaparece de la prueba del momento actual y se aleja del tiempo, se venera por una suposición infundada. Se duda de lo de ahora y se admira lo de antes. Por ejemplo, los muertos antiguos se han hecho dignos de estima por el largo tiempo de error, y los sucesores les han considerado dioses (Clem. Alex. Protr. 4, 55, 2-3).

El paso del tiempo y los relatos mitológicos son, por tanto, la explicación para esta confusión. Sin embargo, la divinidad, en su condición superior, no sólo se encuentra por encima de las pasiones, sino que además no debe ser objeto de lamentos ni sufrimientos por parte de los hombres (Clem. Alex. Protr. 2, 24, 3; 4, 55, 3-4).

Los apologistas latinos mantienen ese tono generalizado, que caracteriza sus descripciones sobre la condición humana de los dioses, en los relatos acerca de las muertes de cada uno de ellos. Una de las referencias más emblemáticas es el reproche que Tertuliano dirige hacia determinadas prácticas paganas: «veo que todavía hay hombres ya civilizados que consagran como dioses a quienes pocos días antes consideraron muertos y sepultaron en medio de un duelo general» (Tert. Apol. 10, 10). Se acepta el hecho de que estos dioses son hombres muertos (Tert. Apol. 11, 1; 12, 1) ${ }^{64}$ pero no se detalla el modo en el que se ha producido su muerte, a excepción de los ejemplos más conocidos de Esculapio (Tert. Apol. 14, 5) ${ }^{65}$ y Hércules. Como Clemente de Alejandría, Tertuliano sitúa la raíz de la confusión en los relatos mitológicos y en las representaciones teatrales que se hacen de estos (Tert. Apol. 14, 2-5; 15, 5). En todos ellos, los dioses son presentados como enemigos, luchando entre sí. Su condición humana se expresa en los trabajos que desempeñan y en los padecimientos que sufren, bien a través de sus heridas físicas, bien por motivos sentimentales (pérdida de un ser querido, enamoramientos, etc.). Esta es la dinámica que presenta el Octavio de Minucio Félix. Aunque éste alude a la muerte de Júpiter, no ofrece detalles sobre la misma, salvo que se produjo en Creta (Min. Fel. Oct. 23, 13). De manera semejante se describe el final de Erígona (ahorcada), Esculapio (fulminado por el rayo), Hércules (consumido por el fuego) o los Castores (Min. Fel. Oct. 22, 7). Las referencias a la muerte de Osiris y la búsqueda de Isis de sus miembros desperdigados por Egipto aparecen perfiladas en su exposición sobre las prácticas rituales egipcias (Min. Fel.

${ }^{64}$ Tertuliano sostiene que nada pueden hacer estos dioses muertos en la protección de los vivos (Apol. 29, 1).

${ }^{65}$ A diferencia de los apologistas anteriores, Tertuliano condena tanto a Júpiter (asesino) como a Esculapio, quien «ejercía la medicina con malas artes», recibiendo por ello «justo castigo a su avaricia» (Apol. 14, 5). Incorpora además un episodio desconocido en el resto de las fuentes acerca de Esculapio: la salvación de Socordio, Tanacio y Asclepiódoto (Apol. 23, 6). Para las diferentes versiones sobre las razones de Asclepio / Esculapio: Sext. Emp. Adv. Math. 1, 260-262. 
Oct. 22, 1) ${ }^{66}$. Los ejemplos de Júpiter, Esculapio, Hércules, Cástor y Pólux son mencionados igualmente por Cipriano de Cartago, quien añade a su narración la muerte de Melicertes y Leucotea, convertidos en dioses marinos después de su muerte (Cypr. Quod idola, 2). El discurso de Arnobio mantiene ese tono generalizado. Además de los ejemplos de Líber, Esculapio (Adv. Nat. 4, 24) $)^{67}$ y Hércules ${ }^{68}$, presentes en toda la literatura apologética, Arnobio incluye la muerte de Rómulo, «dilacerado a manos de cien senadores» (Arnob. Adv. Nat. 1, 41) ${ }^{69}$ y posteriormente divinizado. La única excepción a este modelo de argumentación es la descripción detallada de la muerte de Atis, desangrado después de auto-mutilarse ${ }^{70}$.

\section{LOS SEPULCROS DE LOS DIOSES}

Para los apologistas, la confirmación de que los dioses paganos son seres mortales se demuestra por la existencia de sus tumbas y lugares de enterramiento. De entre todas ellas, la más significativa es la de Zeus, situada en Creta $^{71}$. El primero en aludir a ello es Taciano: «Entre vosotros se muestra el sepulcro de Zeus olímpico, por más que alguno diga que mienten los cretenses» (Tat. Orat. 27). Taciano alude al himno de Calímaco en honor de Zeus, en el que se condena la existencia de una leyenda acerca de su sepulcro ${ }^{72}$. Atenágoras desarrolla más extensamente el reproche de Taciano y junto a los versos de Calímaco expone las razones por las cuales el poeta se equivoca:

Cretenses siempre mentirosos; pues tu sepulcro, oh rey, los cretenses lo fabricaron; pero tú no moriste. Tú, que crees, Calímaco, en el nacimiento de Zeus, te niegas a creer en su sepultura, y pensando echar una sombra sobre la verdad, no haces

\footnotetext{
${ }^{66}$ Minucio alude de forma errónea al hijo de Isis, Horus, en lugar de referirse a su marido y hermano, Osiris.

${ }^{67}$ Como Tertuliano, Arnobio considera que la avaricia fue la causa de su muerte.

${ }^{68} C f$. Arnob. Adv. Nat. 1, 36. Arnobio distingue dos Hércules diferentes. El primero, procedente de Tebas y sepultado en los campos de Hispania. El segundo, tiene su origen en Tiro y se corresponde con la tradición mitológica más popular (muere en la pira del monte Eta). Arnobio relaciona su muerte con la enfermedad de la epilepsia (Adv. Nat. 4, 25).

${ }^{69}$ Liv. 1, 16, 4. Ovidio considera falsa esta versión de la muerte de Rómulo (Ov. Fast. 2, 475-513).

${ }^{70}$ El mito de Atis conoce diferentes versiones. Pausanias recoge dos de ellas. En la primera, Atis es eunuco de nacimiento y se instala en la región de Lidia para celebrar los misterios de Magna Mater. Enfurecido, Zeus envía un jabalí para terminar con las cosechas, que acaba con la vida de Atis (Paus. 7, 17, 9-10). La segunda versión, más popular, es similar a la que describe Arnobio. En un ataque de celos, Agdistis, enamorado de Atis, hace enloquecer a éste, el día de su boda con la hija del rey de Pesinunte. Es entonces cuando Atis decide castrarse a sí mismo, provocándose la muerte (Paus. 7, 17, 10-12). En la versión que ofrece Ovidio, Magna Mater es la responsable de la locura de Atis y del impulso para mutilarse, pues el joven había roto la promesa de castidad que había hecho a la diosa al unirse con la ninfa Sagaritis (Fast. 4, 221-246). Ovidio señala, además, que Atis al morir se transformó en pino (Met.10, 103-105). Para una introducción a la tradición mitológica de Atis, vid. J.N. Bremmer, «Attis: A Greek God in Anatolian Pessinous and Catullan Rome», Mnemosyne 57, 5 (2004), pp. 534-576.

${ }^{71}$ Cic. De nat. deor. 3, 21, 53 .

${ }^{72}$ Calímaco de Cirene (ca. 310-240 a.C.), Hymn. in Jov. 8-9. La misma expresión es mencionada por el apóstol Pablo en su Epistola a Tito (Tt. 1, 12).
} 
sino predicar un muerto aún a quienes no lo conocen. Si miras a la cueva, te acuerdas del parto de Rea; pero si te fijas en el ataúd, echas una sombra sobre el muerto, y es que no sabes que sólo es eterno el Dios increado (Athenag. Leg. 30, 3).

En la refutación de los versos de Calímaco, Atenágoras recupera el debate en torno al carácter eterno de lo divino. En la concepción cristiana, Dios no tiene principio ni fin, de manera que, si el poeta griego acepta el origen y nacimiento de Zeus ${ }^{73}$, está negando al mismo tiempo uno de los fundamentos de la divinidad. De nada sirve entonces que trate de contradecir la leyenda acerca de la existencia de su tumba. La alusión al enterramiento de Zeus en Teófilo de Antioquía, más concisa que la de los apologistas precedentes, se limita a exponer que en Creta, «se enseña hasta el presente su sepulcro» (Theoph. Ad Autol. 2, 3; 1, 10). El mismo modelo de argumentación de Atenágoras - mediante la refutación de los versos de Calímaco- es utilizado posteriormente por Clemente y Orígenes (Clem. Alex. Protr. 2, 37, 4; Orig. C. Cels. 3, 43). Este último responde a la acusación de Celso contra los cristianos por utilizar el sepulcro de Zeus como un argumento que demuestra su condición mortal.

En los apologistas latinos también se menciona el sepulcro de Zeus / Júpiter. Minucio Félix señala que la ubicación de esta tumba es un hecho reconocido y aceptado por todos, cuando precisa que «todavía se visita hoy la gruta de Júpiter y se enseña su sepulcro» (Min. Fel. Oct. 23, 13). En términos semejantes se expresan Cipriano (Cypr. Quod idola, 2) y Arnobio (Arnob. Adv. Nat. 4, 25). Tertuliano alude a este enterramiento en un contexto argumentativo diferente al de los otros apologistas, tanto anteriores como posteriores a él. En su exposición sobre la falta de poder demostrada por los dioses paganos, incapaces de proteger a sus diferentes pueblos de la dominación romana, Tertuliano pone el ejemplo de Júpiter, que nada hizo por la tierra en la que había nacido. Irónicamente, Tertuliano sugiere que posiblemente Júpiter hubiera preferido ser enterrado en el Capitolio en lugar de en «aquel túmulo suyo» en la isla de Creta (Tert. Apol. 25, 7). Lactancio es quien ofrece más detalles acerca de la tumba de Zeus. No sólo precisa la ubicación exacta del sepulcro, en la ciudad de Knossos, sino que describe la inscripción que puede leerse en ella: «ZAN KRONOU», que traduce al latín como «Júpiter de Saturno» (Lact. Div. Inst. 1, 11, 46).

El ejemplo del sepulcro de Zeus / Júpiter en Creta se convirtió en uno de los testimonios más destacados por los apologistas para demostrar la mortalidad de los dioses paganos. Teófilo de Antioquía señala que, si no se conservan otras sepulturas de dioses diferentes, probablemente se deba a que «no se los tuvo quizá por dignos ni de sepultura» (Theoph. Ad Autol. 1, 10). No obstante, Taciano recoge otro ejemplo distinto al del enterramiento de Zeus para confirmar esta hipótesis, el sepulcro de Dioniso, situado en un espacio conocido como el Ombligo, «en el sagrado recinto del hijo de Leto», es decir, en el santuario de Apolo (Tat. Orat. 8). El testimonio más prolijo acerca de los diferentes lugares de enterramiento de los dioses paganos lo ofrece el Protréptico de Clemente de Alejandría, quien afirma que Asclepio «yace

${ }^{73}$ Callim. Hymn. in Jov. 6-8 y 10. 
fulminado en los límites de Cinosuris» (Clem. Alex. Protr. 2, 30, 2-4) ${ }^{74}$. Según el testimonio de Filócoro, Posidón es venerado en Tenos y Cronos está enterrado en Sicilia, donde es honrado «con ritos funerarios». La tradición mitológica confirma que los Dioscuros se encuentran en su patria (Lacedemonia) ${ }^{75}$ y Heracles en el monte Eta. Además de estos personajes mitológicos, son mencionados, igualmente, los lugares de enterramiento de otras figuras veneradas por los hombres (Clem. Alex. Protr. 3, $45,1-4)^{76}$.

Los primeros apologistas latinos aluden a la existencia de los diferentes enterramientos de los dioses, aunque no especifican su localización. Tertuliano menciona las tumbas de los dioses entre los «monumentos de la Antigüedad», pero no precisa los detalles sobre ninguna de ellas (Tert. Apol. 10, 4). El argumento vuelve a recuperarse con los apologistas posteriores. Arnobio reproduce la misma lista de referencias mencionada por Clemente de Alejandría (Arnob. Adv. Nat. 4, 25; 6, 6) ${ }^{77}$, e incorpora, además, otro testimonio diferente, afirmando que en el Capitolio de Roma se encontraba el sepulcro de Olo Vulcentano o Aulo (Arnob. Adv. Nat. 6, 7). Aunque no se trata de una divinidad, Arnobio alude a este personaje para explicar la etimología del Capitolio, el centro religioso del mundo romano. Durante el reinado de Tarquinio el Soberbio, con las obras realizadas para la construcción del templo de Júpiter, Juno y Minerva, fue exhumada la cabeza de Olo, que había sido enterrada allí en secreto ${ }^{78}$. El propósito que persigue Arnobio con su argumentación es vincular las tumbas de los dioses de la mitología con los lugares de adoración de los fieles paganos, para equiparar a los templos con lugares de enterramiento:

¿No se demuestra en los escritos de los historiadores que muchos de estos templos que se han elevado con cúpulas de oro y techumbres excelsas cubren cenizas y huesos y son sepulcros de cuerpos difuntos? ¿No es claro y evidente que vosotros, o bien honráis a muertos en lugar de dioses inmortales o hacéis una irreparable afrenta a los dioses, cuyos templos y altares surgen sobre tumbas de difuntos? (Arnob. Adv. Nat. 6, 6).

\footnotetext{
${ }^{74}$ Cic. De nat. deor. 3, 22, 57. La ubicación de esta localidad es incierta; probablemente en Arcadia.

${ }^{75}$ Hom. Il. 3, 243-244.

${ }^{76}$ Entre otros, Clemente alude a los sepulcros de Acrisio, rey de Argos, y Cécrope, fundador legendario de Atenas. El primero se sitúa en el templo de Atenea, en la acrópolis de Larisa (ciudadela de Argos), mientras que el segundo se localiza en la acrópolis ateniense (Antiochus Syracusanus, Frag. 15 [F.H.G. vol. 1, p. 184]). En este mismo lugar se encuentra la tumba de Erictonio, rey mítico de Atenas (Apollod. Bibl. 3, 14, 6-7). En el santuario de Eleusis, las tumbas de Immarado, el hijo de Eumolpo, y Daira; y en el templo de Ceres, las hijas de Celeo (Hymn. Dem. 145-300; Apollod. Bibl. 1, 5, 1). Las hijas de los hiperbóreos, Hipéroce y Laodice, están enterradas en Delos, en el Artemisio (Hdt. 4, 33, 3-4 y 34, 1-2), mientras que Cleoco lo está en el Didimeo de Mileto (Leandrius, Frag. 5 [F.H.G. Vol. 2, p. 336]). La tumba de Leucrofrine se sitúa en el templo de Artemis en Magnesia, la de Telmeso en el altar de Apolo, y la de Ciniras y sus descendientes en el santuario de Afrodita (Ptol. Megalop. Frag. 1 [F.G.H. Vol. 3, p. 66]). A esta amplia lista Clemente incorpora también la tumba de Antínoo (Protr.4, 49, 3).

${ }^{77}$ Las referencias son idénticas, aunque los textos presentan algunas variantes en lo concerniente a las fuentes.

${ }^{78}$ De la cabeza de Olo recibe su nombre el Capitolio $($ Capitolium $=$ Caput + Olus $)$.
} 
Arnobio afirma que, a excepción de los egipcios, quienes tienen prohibido revelar el lugar de enterramiento de Apis, la lista de ejemplos de las tumbas de los dioses es inmensa y que el propio Varrón utiliza el término polyandria, aludiendo a los cementerios o sepulcros, para definir el espacio que es cubierto por los templos paganos.

La equiparación entre los templos y las tumbas se encuentra en otros apologistas. Así lo expresa Clemente de Alejandría cuando afirma: «los lugares consagrados a los ídolos son ciertas tumbas o prisiones» (Clem. Alex. Protr. 10, 91, 1). Clemente dedica el tercer capítulo del Protréptico a esta cuestión, afirmando que «se les llama templos por eufemismo, pero son tumbas» (Clem. Alex. Protr. 3, 44, 4) ${ }^{79}$. Este error es una práctica extendida entre los paganos y, con el propósito de demostrarlo, expone el ejemplo del culto a Antínoo:

Ahora existe una tumba del amado, un templo y una ciudad de Antínoo. Y, según creo, se admiran los templos del mismo modo que las tumbas, las pirámides, los mausoleos y los laberintos, otros templos de los muertos como aquellas tumbas de los dioses (Clem. Alex. Protr. 4, 49, 3).

Una prueba de que la identificación de los templos paganos con tumbas es una idea ampliamente difundida entre los cristianos (Athenag. Leg. 28, 7) reside en el hecho de que Cecilio, el interlocutor pagano del diálogo Octavio, menciona este reproche. En su descripción sobre la actitud de los cristianos, señala que éstos «desprecian los templos como si fueran tumbas» (Min. Fel. Oct. 8, 4). A partir de esta imagen, la literatura apologética desarrolla un tema recurrente: la identificación del paganismo con la muerte, en contraposición al cristianismo, que simboliza la vida. La divinización de los hombres después de la muerte que, en esencia, es lo que representan los dioses del paganismo, para los cristianos constituye, junto a esta identificación de los templos con sepulcros, la demostración de que su veneración es una forma particular de adorar a los muertos. La idea ya está presente en Justino cuando establece las diferencias de ritual entre el modelo cristiano y el pagano en el culto a los difuntos: «Y esto es lo único que vosotros nos podéis recriminar, que no veneramos los mismos dioses que vosotros, y que no ofrecemos a los muertos libaciones y grasas, no colocamos coronas en los sepulcros ni celebramos allí sacrificios» (Just. 1 Apol. 24, 2).

Atenágoras dirige su atención hacia las ceremonias rituales paganas y sostiene que dichas celebraciones se asemejan a los actos rituales de carácter funerario, puesto que en ellas los fieles «se golpean los pechos», como se hace por los muertos, y después los «entierran en los templos y organizan públicos duelos» (Athenag. Leg. 14, 2). Apoyándose en el testimonio de Heródoto y sus descripciones sobre las celebraciones de los misterios en honor de Isis y Osiris ${ }^{80}$, Atenágoras considera que este

\footnotetext{
${ }^{79}$ La idea es constante a lo largo de toda la obra (Protr. 4, 56, 2).

${ }^{80}$ Hdt. 2, 61; 2, 86; 2, 170. Heródoto señala que estas celebraciones en honor de Osiris se desarrollan junto al sepulcro del dios (Neith), en el templo de Atenea.
} 
modo de actuar «no es piadoso», pues, los sufrimientos de los dioses únicamente revelan su condición humana, perdiendo de esta manera su carácter sagrado (Athenag. Leg. 28, 8-10). Clemente de Alejandría expone el mismo reproche utilizando el testimonio original de Jenófanes: «Si los consideráis dioses, no los lloréis, ni os hagáis daño; y, por el contrario, si os lamentáis por ellos, ya no creáis que son dioses» (Clem. Alex. Protr. 2, 24, 4) y sostiene que el primero en introducir este tipo de prácticas fue Orfeo, poseído «por los demonios y mediante un hábil encantamiento». Con su testimonio se establece «la costumbre más vil» entre los paganos, quienes «celebran, como si fueran ceremonias religiosas, actos de orgullo y divinizan las ceremonias fúnebres» (Clem. Alex. Protr. 1, 3, 1). Esta identificación de las ceremonias religiosas paganas y los ritos funerarios es constante a lo largo del Protréptico. De hecho, en la narración de Clemente no siempre resulta posible distinguir unos actos de otros, y prueba de ello es la descripción de las muertes de las divinidades paganas. En su retórica se mezclan las alusiones a las celebraciones funerarias con los ritos de adoración a los dioses (Clem. Alex. Protr. 2, 30, 3 y 7; 3, 45, 1 y 3-4), e incluso con los juegos y espectáculos públicos consagrados a alguna divinidad (Clem. Alex. Protr. $2,34,1)$. El retrato que ofrece sobre los devotos que participan en tales rituales es una evidencia de este desprecio:

Tienen manchada la cabeza, destrozan sus vestidos sucios y rotos. Desconocen por completo los baños y parecen animales salvajes por sus afiladas uñas. Muchos también se han castrado y se muestran, de hecho, que los lugares consagrados a los ídolos son ciertas tumbas o prisiones. Me parece que éstos, en vez de adorar a los dioses, los lloran, soportando hechos más dignos de compasión que de piedad (Clem. Alex. Protr. 10, 91, 1).

Esta práctica, por tanto, debe ser erradicada, puesto que sólo conduce a la perdición de los hombres: «Si no sentís vergüenza por estos atrevimientos, terminaréis cadáveres, porque habéis puesto vuestra confianza realmente en los muertos» (Clem. Alex. Protr. 3, 45, 5). La descripción de Tertuliano es una de las más representativas, en cuanto que establece una comparación directa entre las prácticas paganas, cuyas ceremonias conoce «a través de las leyendas» (Tert. Apol. 12, 1), y los actos celebrados en honor a los muertos:

¿Qué hacéis en su honor que no tributéis también a vuestros muertos? Templos, como a ellos; aras, como a ellos; el mismo aspecto y los mismos atributos en las estatuas. Según la edad, los conocimientos, la actividad del muerto, así los del dios. ¿En qué se diferencia un banquete fúnebre del festín de Júpiter, una copa de libaciones fúnebres de las que sirven para las libaciones sacrificiales; un embalsamador de un arúspice? Pues también el arúspice asiste a los muertos. Es natural que decretéis honores divinos a los emperadores muertos, puesto que se los tributáis en vida. Lo aceptarán vuestros dioses; más aún, se congratularán de que sus dueños se igualen a ellos (Tert. Apol. 13, 7). 
Minucio Félix describe en términos semejantes los ritos celebrados en honor de Isis, en Egipto. Con sus actos, los sacerdotes que lideran estas ceremonias imitan el sufrimiento de Isis ante la pérdida de Osiris, golpeándose el pecho y gimiendo de dolor (Min. Fel. Oct. 22, 1).

\section{JESÚS Y LOS SERES DIVINIZADOS DEL PAGANISMO}

La argumentación de Orígenes en relación a la condición humana de los dioses difiere de la expuesta por los apologistas anteriores. Como hemos señalado, su discurso está condicionado por las críticas del pagano Celso sobre el carácter divino de Jesús ${ }^{81}$. Orígenes trata de mostrar las diferencias entre las muertes padecidas por los dioses paganos y la de Jesús:

En cuanto a su muerte, se debió a la conjura de los hombres y nada tuvo que ver con el rayo que hirió a Asclepio. ¿Y qué tiene de sagrado el furioso Dioniso, vestido de mujer para que se lo adore como a dios? Mas si los que defienden estos mitos se acogen a las alegorías, hay que averiguar puntualmente si las tales alegorías contienen algo sano; y averiguar puntualmente también si, quienes fueron despedazados por los titanes y derribados del trono celeste, pueden tener existencia real y ser dignos de culto y adoración (Orig. C. Cels. 3, 23).

Dos críticas se desprenden del pasaje citado. En primer lugar, el rechazo a las interpretaciones alegóricas de los relatos mitológicos, como una demostración de la inexistencia de tales personajes. En segundo lugar, la idea sobre la dignidad del comportamiento de estos hombres para adquirir la condición divina. Orígenes explota este argumento mejor que ningún otro apologista. Empleando el recurso de la retorsio, los ejemplos que el propio Celso menciona para confirmar que, tal y como sucede con Jesús, no es posible divinizar a un ser mortal son utilizados por Orígenes para dirigirlos contra su adversario. Apoyándose en las razones expuestas por Celso precisamente para desacreditarlos, personajes como Aristeas de Proconeso (Orig. $C$. Cels. 3, 26-29) ${ }^{82}$, Abaris el hiperbóreo (Orig. C. Cels. 3, 31) ${ }^{83}$, Hermótimo de Clazomenias (Orig. C. Cels. 3, 32) ${ }^{84}$ o Cleomedes de Astipalea (Orig. C. Cels. 3, 33; 3, $25)$, se convierten en la excusa de Orígenes para demostrar que es necesario exhibir un comportamiento apropiado si se desea alcanzar la condición divina (Orig. C. Cels. 3,42 ). Además, contrapone a la figura de Jesús no sólo su comportamiento, sino también los supuestos beneficios que reportan los humanos divinizados (Orig. C. Cels. $3,28 ; 3,31 ; 3,34 ; 3,42)$. Frente a la salvación y la vida eterna que concede el Hijo

\footnotetext{
${ }^{81}$ Sobre la argumentación de Orígenes, vid. H.Y. Gamble, «Euhemerism and Christology in Origen: Contra Celsum III 22-43», VC 33, 1 (1979), pp. 12-29.

${ }^{82}$ Hdt. 4, 14, 1-3 y 15, 1-4; Plin. N.H. 7, 52(52), 174.

${ }^{83}$ Hdt. 4, 36, 1.

${ }^{84}$ Plin. N.H. 7, 52(52), 174; Plu. De gen. Soc. 22 [592c-e].
} 
de Dios, aquellos hombres «ningún bien hicieron al género humano: ¿Qué acción puede hallarse de estos hombres comparable con la obra de Jesús y sus milagros, de que largamente hemos hablado?» (Orig. C. Cels. 3, 34). Las desapariciones milagrosas que alegan los relatos literarios sobre algunos de estos personajes no son motivo suficiente para su equiparación con Jesús (Orig. C. Cels. 3, 26; 3, 33) ${ }^{85}$. Por el contrario, para Orígenes constituyen la evidencia de las incoherencias que presenta el discurso de Celso: «Te nos presentas creyendo en tamañas patrañas, sin alegar una prueba ni demostración de que efectivamente sucedieron» (Orig. C. Cels. 3, 27; 3, $28 ; 3,33)$. El autor destaca la creencia sin fisuras acerca de tales historias de Celso quien, por el contrario, se muestra escéptico en relación a los cristianos, pese a que cuentan con testigos directos de lo sucedido con Jesús (Orig. C. Cels. 3, 23-24). Para el apologeta el poder curativo de Asclepio - en comparación a los milagros realizados por Jesús- presenta el mismo problema (Orig. C. Cels. 3, 24; 7, 35). Las dotes adivinatorias o las curaciones no son en sí mismas motivo de deificación. De hecho, los oráculos han apuntado a la divinización de determinadas personas, cuyo comportamiento -reconocido por todos-nada tiene de divino (Orig. C. Cels. 3, 25) ${ }^{86}$. Celso compara la divinización de Jesús con otras prácticas de pueblos diferentes: el culto a Zamolxis entre los getas; a Mopso, por los cilios ${ }^{87}$; a Anfíloco, entre los arcamenses; a Anfiarao, por los tebanos ${ }^{88}$; y a Trofonio, por los lebadios. La respuesta de Orígenes se centra en las diferencias de los rituales de culto entre unos y otros. Mientras aquéllos levantan «templos y estatuas», los cristianos los rechazan, «pues los tenemos por más acomodados a los espíritus demónicos que, no sé por qué manera, ora lo conviertan como en morada suya, atraídos por ciertas iniciaciones o magias» (Orig. C. Cels. 3, 34; 7, 35). Aunque para desacreditar los cultos paganos Orígenes se apoya en las mismas razones que el resto de los apologistas (la intemperancia de los dioses, su condición mortal, sus defectos, etc.), su discurso, enriquecido con otros ejemplos, se caracteriza por la utilización de la figura de Jesús como eje fundamental sobre el que articular el desarrollo de su argumentación. Así, al tiempo que responde a las acusaciones dirigidas contra los cristianos, formula su condena del paganismo en un tono polémico, a través de un ejercicio de carácter comparativo de la figura de Jesús y las divinidades paganas. Orígenes es el principal exponente de este modelo de argumentación que alcanza su máximo desarrollo en los apologistas latinos posteriores, como Arnobio o Lactancio.

La idea, sin embargo, no es nueva. Son los primeros apologistas latinos, Tertuliano y Minucio Félix, quienes sientan las bases para este discurso, al expresar sus respuestas contra las acusaciones formuladas por los intelectuales paganos de la segunda mitad del siglo II. No obstante, el primer escritor cristiano que alude a los reproches de los

\footnotetext{
${ }^{85}$ Para Orígenes, el objetivo de estos relatos literarios no es otro que desacreditar aquello que se había profetizado acerca de Jesús (C. Cels. 3, 32).

${ }^{86}$ Entre otros, Cleomedes y Arquíloco. Orígenes destaca que el propio Apolo mantiene una actitud inmoral con la profetisa de la Pitia (C. Cels. 7, 3).

${ }^{87}$ Cic. De nat. deor. 2, 3, 7. Mopso fue un vidente, hijo de Apolo y de Mantó, la hija de Tiresias.

${ }^{88}$ Cic. De nat. deor. 2, 3, 7; Anfiarao, vidente y héroe de la saga argivo-tebana.
} 
paganos y relaciona ambos conceptos (el carácter divino de Jesús en contraposición a la condición humana y mortal de los dioses de la mitología) es Justino (Just. 1 Apol. 13, 3) ${ }^{89}$ :

Si se nos echa en cara que fue crucificado, también esto es común con los antes enumerados hijos de Zeus que vosotros admitís haber sufrido. Y, en efecto, cuéntase de ellos que no sufrieron un mismo género de muerte, sino diferentes; de suerte que ni en el hecho de haber sufrido una pasión particular se queda atrás respecto de aquéllos, antes bien, andando el discurso demostraremos serles muy superior o, por mejor decir, ya está demostrado, pues él que es superior se muestra por sus obras (Just. 1 Apol. 22, 3-4).

El interés de los apologistas acerca del origen de los dioses del paganismo tiene el propósito de mostrar su condición humana. Una cuestión que está directamente relacionada con los reproches que los paganos dirigen contra la figura de Jesús ${ }^{90}$. Las descripciones que los apologistas ofrecen sobre el nacimiento y la muerte de los dioses paganos constituyen, en esencia, la devolución de la misma acusación que ellos han recibido:

Hasta el vulgo sabe ya que Cristo fue un hombre, tal y como pensaron los judíos: por lo que fácilmente se nos puede tener por adoradores de un hombre. La verdad es que no nos avergonzamos de Cristo, ya que nos agrada que se nos considere y se nos castigue en nombre suyo [....] Aceptad por el momento esta fábula (se parece a las vuestras) hasta que demos a conocer de qué modo se prueba la existencia de Cristo, y quiénes de entre vosotros han hecho correr fábulas semejantes a ésta, para destruir la verdad de ésta (Tert. Apol. 21, 3 y 14).

Como puede verse en el pasaje citado, Tertuliano no niega la condición humana de Jesús, como tampoco lo hacen el resto de los apologistas ${ }^{91}$. Por el contrario, opta por equiparar esta naturaleza a la que presentan los mitos del paganismo para, a continuación, establecer las diferencias que existen entre unos y otros ${ }^{92}$. Apoyándose en los textos de la Sagrada Escritura, Tertuliano describe los prodigios y milagros de Jesús (Tert. Apol. 21, 17 y 19$)^{93}$ que en nada se asemejan a los realizados por los demonios.

\footnotetext{
${ }^{89}$ Según el relato de Justino, los paganos califican de locura la creencia cristiana. En este contexto retórico se entiende la precisión que ofrece acerca del origen de Perseo y de Atenea en comparación con el nacimiento virginal de Jesús (1 Apol. 22, 5).

${ }^{90}$ Atenágoras también alude a este reproche sobre la condición humana de Jesús. Sin embargo, en su argumentación no hay una relación directa entre la muerte de Jesús y el carácter mortal que presentan los dioses del paganismo (Leg. 10, 2).

${ }_{91}$ El misterio de la Encarnación de Jesús es descrito en el capítulo 21 del Apologético.

${ }^{92}$ La misma idea en Apol. 23, 12-13, donde se expone la tarea asignada por Dios a Jesús de juzgar las almas de los hombres después de la resurrección de los cuerpos, en oposición a las figuras mitológicas de Minos y Radamante.

${ }^{93}$ Entre otros, Tertuliano alude a: la expulsión de demonios (Mt. 4, 24; 8, 16; 8, 28-34; 15, 21-28; 12, 22; 17, 14-18; Mc. 1, 23-28; 9, 18-27; Lc. 4, 33, 35); curación de ciegos (Mt. 9, 27-31; 20, 29-34; Mc. 8, 22-26; Lc. 18, 35-43; Jn. 9, 1-41), leprosos (Mt. 8, 1-4; Mc. 1, 40-45; Lc. 17, 12-19) y paralíticos (Mt. 9, 2-7; Mc. 2,
} 
El objetivo de éstos, dirigiéndose «a unos hombres aún rudos y salvajes», a quienes es fácil asombrar, es ponerlos a su servicio. Jesús, en cambio, pretende hacer «reconocer la verdad a hombres ya civilizados». Es la forma que tiene Dios de «darse a conocer» a los hombres (Tert. Apol. 21, 28 y 30-31). Minucio Félix recoge este mismo reproche acerca de la condición mortal de Jesús, aunque no lo menciona directamente por su nombre:

Así, cuando nos imputáis que nuestra religión adora a un hombre criminal y a su cruz, os alejáis mucho de los senderos de la verdad, al pensar que un criminal ha merecido o un ser terreno ha podido ser creído un dios. ¿Acaso no es un miserable quien pone toda su esperanza en un hombre mortal?, porque todo su amparo acaba con la desaparición de ese hombre (Min. Fel. Oct. 29, 2-3).

El pasaje citado es uno de los más controvertidos según la crítica, puesto que el autor parece eludir precisamente las referencias a la figura de Jesús ${ }^{94}$. A excepción de este pasaje, no hay en la obra ninguna referencia a la persona de Cristo ni a los principales dogmas cristianos. Tampoco menciona ningún texto evangélico, caso excepcional junto con el de Taciano en el conjunto de la literatura apologética ${ }^{95}$. Existen varias líneas de interpretación para explicar esta omisión ${ }^{96}$, aunque mayoritariamente se considera que estas ausencias se relacionan con el destinatario del diálogo: la sociedad romana. Se trata, por tanto, de una omisión deliberada de aquellos elementos que pudiesen resultar inaceptables para los razonamientos paganos; una forma de acercar el cristianismo a los ciudadanos romanos cultos mediante el uso de un lenguaje y un estilo familiar, explicándose así la perspectiva filosófica de su argumentación ${ }^{97}$. En este contexto retórico se entiende la negación de Minucio Félix sobre

1-12; Jn. 5, 1-15), resurrecciones (Mt. 9, 18-26; Mc. 5, 35-43; Lc. 7, 11-17; Jn. 11, 11-44), el dominio ejercido sobre los elementos, aplacando tempestades (Mt. 8, 23-27; Mc. 4, 35-41), caminando sobre las aguas (Mt. 14, 24-33), oscureciendo el sol en mitad del día en el momento de su muerte (Mt. 27, 45; Mc. 15, 33; Lc. 23, 4445), o ascendiendo a los cielos (Mt. 28, 16-20; Mc. 16, 15-19; Lc. 24, 50).

94 Octavio responde a la acusación de Cecilio de venerar «a un hombre castigado al mayor suplicio por su delito y la madera funesta de una cruz» (Min. Fel. Oct. 9, 4).

95 Cfr. J. Torres, op. cit., 2013, pp. 27 y 52.

${ }^{96}$ La primera, ya superada, considera que Minucio Félix es un converso reciente, sin un conocimiento profundo de los dogmas cristianos; J. Beaujeu sostiene que es una omisión voluntaria para evitar contrariar las tesis oficialistas de las autoridades eclesiásticas (J. Beaujeu, op. cit., pp. xvii-xix), mientras que J.-M. Vermander considera que Minucio Félix no tendría nada que añadir a lo dicho por Tertuliano sobre una cuestión tan controvertida (J.-M. Vermander, «Celse, source et adversaire de Minucius Felix», REAug 17 (1971) p. 25). S. Bodelón cree que la conversión de Minucio Félix se debe a necesidades tácticas, pero que no conoce los dogmas en profundidad (S. Bodelón, «El discurso antipagano de Octavio en la obra de Minucio Félix», MHA 15-16 (1994-1995) p. 137-138).

97 A.M. Aldama Roy, «El Octauius de Minucius Felix: puntos discutidos», EClá 29, 91 (1987) pp. 60-62; S.R.F. Price, «Latin Christian Apologetics: Minucius Felix, Tertullian, and Cyprien», M. Edwards, M. Goodman y S. Price (eds.), op. cit., pp. 123-124; V. Sanz Santacruz, op. cit., pp. 33-38; 123, n. 311; 124, n. 317; C. Ames, «La apología y el diálogo en los primeros apologistas latinos: Tertuliano y Minucio Félix», CIRCE 12 (2008) pp. 46-52; J. Torres, «Recursos retóricos en la polémica literaria entre cristianos y paganos (ss. II-V): el género del diálogo», De Cara al Más Allá. Conflicto, convivencia y asimilación de modelos paganos en el cristianismo antiguo, Zaragoza, 2010, p. 106. Sobre la problemática en torno a los destinatarios y la intencionalidad 
la adoración de las cruces por los cristianos (Min. Fel. Oct. 29,6) y sólo de manera indirecta, que Jesús sea un criminal o un simple hombre.

Por el contrario, el elemento más significativo de la argumentación de Arnobio reside en que ésta responde directamente a la acusación dirigida contra los cristianos sobre la muerte de Jesús en la cruz. Arnobio sostiene que, según los relatos mitológicos, las divinidades paganas soportaron injurias semejantes a las padecidas por Cristo (Arnob. Adv. Nat. 1, 36; 1; 41; 5, 31):

Por lo tanto, o hay que reírse de vosotros porque consideráis que hombres muertos con gravísimos suplicios son dioses y les rendís culto, o si hay una razón bien válida para que consideréis que esto deba hacerse, permitidnos a nosotros también el tener nuestros motivos y razones para hacerlo (Arnob. Adv. Nat. 1, 41).

Para Arnobio, el hecho de que Jesús haya tenido una muerte violenta no significa que deba cuestionarse por ello la autoridad de su doctrina. De modo semejante se produjeron las muertes de Pitágoras, Sócrates, Aquilio, Trebonio o Régulo, entre otros (Arnob. Adv. Nat. 1, 40). Su discurso se completa con una afirmación algo particular entre los apologistas, pues mantiene que no fue Jesús quien murió en la cruz, ya que «la muerte no puede abatirse sobre lo que es divino». En realidad, quien muere es «el hombre del que se había revestido y que Él llevaba consigo». Para evitar confusión a sus lectores, Arnobio ofrece una analogía dentro del contexto religioso pagano como aclaración. Si una divinidad pagana pronuncia un oráculo a través de un adivino en el momento preciso en el que éste muere, los paganos no considerarán en ningún caso que quien muere es el dios, sino el hombre, que actuaba como su vehículo de transmisión (Arnob. Adv. Nat. 1, 62). El mismo procedimiento es el que debe aplicarse para la muerte de Jesús. Frente a ello, Arnobio sostiene que los dioses paganos tienen una naturaleza corruptible y están sometidos a la voluntad de Dios, quien decide su aniquilación o conservación (Arnob. Adv. Nat. 2, 36).

\section{CONCLUSIONES}

El evemerismo está presente, al menos, en tres contextos de la argumentación apologética. En primer lugar, los apologistas lo emplean para desacreditar a los dioses paganos y negar así su divinidad al insistir en su naturaleza humana. Este planteamiento se extiende a la figura de los gobernantes, divinizados después de su muerte, enlazando con el segundo contexto de la argumentación: el rechazo cristiano a participar en las ceremonias del culto imperial. Este rechazo se expresa, según los apologistas, en términos estrictamente religiosos y no políticos, al considerar que a las auto-

de la literatura apologética, vid. M. Rizzi, Ideologia e retorica negli «exordia» apologetici. Il problema dell' «altro», Milano, 1993; S.R.F. Price, op. cit., pp. 105-129; A.-C. Jacobsen, «Main Topics in Early Christian Apologetics», A.-C. Jacobsen, J. Ulrich y D. Brakke (eds.), op. cit., pp. 85-110; Idem. "Apologetics and Apologies - Some Definitions», J. Ulrich, A.-C. Jacobsen y M. Kahlos (eds.), op. cit., pp. 5-21. 
ridades se les debe mostrar respeto pero no la veneración propia de los dioses. Por último, el evemerismo se asocia también a las críticas formuladas desde el entorno pagano sobre la condición humana de Jesús.

La utilización del evemerismo como recurso retórico ejemplifica el modelo del discurso apologético, pues estos tres contextos se corresponden con los tres modelos de argumentación característicos:

1) El discurso polémico mediante la reutilización de argumentos previos. La interpretación evemerística de los dioses tiene una larga tradición en el mundo griego antes del cristianismo. Los apologistas utilizan y readaptan esta teoría para formular su diatriba contra el paganismo.

2) El discurso protréptico que justifica el comportamiento de los cristianos. Mediante el evemerismo, los apologistas explican su rechazo a participar en las ceremonias del culto imperial, al tiempo que exhortan a la conversión, exponiendo los errores que presenta la sociedad greco-romana frente al correcto comportamiento cívico que exhiben los cristianos.

3) El discurso estrictamente apologético o defensivo, en respuesta a las críticas sobre la condición humana de Jesús. Para ello, los apologistas emplean el recurso retórico de la retorsio, proyectando sobre sus adversarios los mismos reproches que previamente habían recibido; es decir, recriminando a los paganos una creencia idéntica.

No obstante, en este modelo de argumentación se advierte que no hay un discurso apologético en sentido estricto, pues los apologistas no se defienden de las acusaciones; es decir, no explican ni justifican las críticas dirigidas a Jesús. Es posible, como señalábamos anteriormente para el caso de Minucio Félix, que la figura de Jesús resultase demasiado controvertida ante un público no cristiano, supuesto destinatario de estos tratados. En todo caso, esta ausencia de una respuesta defensiva, a excepción de algunos breves pasajes, es una tónica generalizada en el discurso apologético ante otras acusaciones (como la antropofagia, el incesto, la deslealtad cívica, etc.). En la mayor parte de las ocasiones no hay una argumentación elaborada ni extensa sobre la inocencia de los cristianos. Aunque la audiencia de los tratados sea externa y por tanto ajena a los fundamentos teológicos del cristianismo, no se encuentra en los apologistas una explicación sistemática de la doctrina y el ritual cristiano. El discurso apologético se centra en negar estas acusaciones y en proyectar sobre los paganos los mismos reproches; es decir, la defensa del cristianismo se formula en términos polémicos, elaborando, a menudo, una imagen depravada del paganismo de carácter estereotipado. 